Portland State University

PDXScholar

1979

\title{
The political and constitutional origins of the Grand Remonstrance
}

James S. Hart Jr.

Portland State University

Follow this and additional works at: https://pdxscholar.library.pdx.edu/open_access_etds

Part of the European History Commons, and the Political History Commons Let us know how access to this document benefits you.

\section{Recommended Citation}

Hart, James S. Jr., "The political and constitutional origins of the Grand Remonstrance" (1979). Dissertations and Theses. Paper 2886.

https://doi.org/10.15760/etd.2880

This Thesis is brought to you for free and open access. It has been accepted for inclusion in Dissertations and Theses by an authorized administrator of PDXScholar. Please contact us if we can make this document more accessible: pdxscholar@pdx.edu. 
AN ABSTRACT OF THE THESIS OF James $\mathrm{S}$. Hart $\mathrm{Jr}$. for the Master of Arts in History presented May 1, 1979.

Title: The Political and Constitutional Origins of the Grand Remonstrance

APPROVED BY MEMBERS OF THE THESIS COMMITTEE:

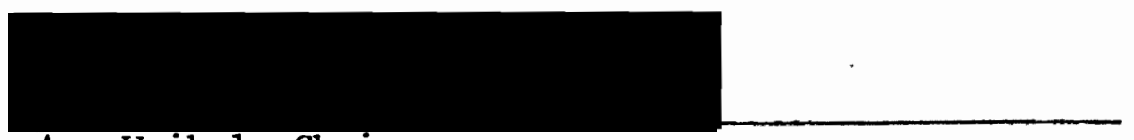

$$
\text { Ann Weikel, Chairman }
$$

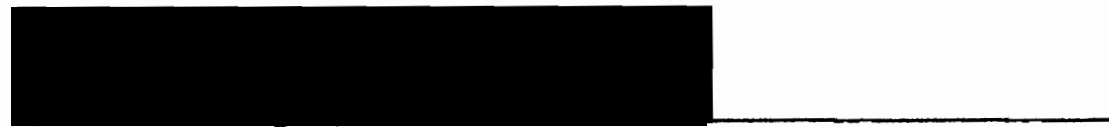

Michael Reardon

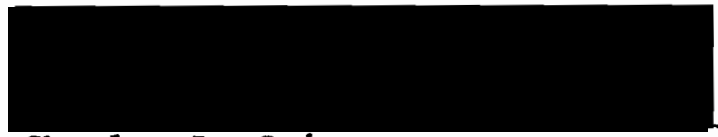

Charles Le Guin

This thesis on the Grand Remonstrance represents an attempt to deal with the central question of Stuart Historiography, the question which asks "What were the causes of the English Civil War, and why did it occur when it did?" The question of causation is fundamental to an understanding of the early 17 th century, and it has created considerable controversy among successive generations of historians. The central issue in question is whether the English Civil War was caused by a long term revolution in English society, generated by substantial changes in socio-economic conditions, or whether, in fact, it was caused by a fundamental breakdown in the 
working relationship between a particular monarch and a particular representative body. The choice of the Grand Remonstrance as the subject of the thesis was made after considerable study in the period led me to believe that the latter theory was correct, and furthermore, that a careful study of the Grand Remonstrance, and its relationship to the Long Parlament would provide important evidence to support that hypothesis. I realized when I made the decision that I had chosen a piece of parliamentary reform that spanned, in its development, a full year of parliamentary history, and that I had, therefore, committed myself to a study of rather sizable proportions, both chronologically and topically. Nonetheless, I have tried to limit the study to the history of the Remonstrance itself, and to the issues which directly influenced i.ts development, and which clearly reflected the political conditions prevailing in England immediately prior to the Civil War.

This study of the Remonstrance was made possible because of the:availability of a number of primary sources which documented the day to day activities of the Long Parliament. The principle primary sources were: The Journals of the House of Commons, the Journal of Sir Simonds D'Ewes, Rushworth's Historical Collections, Sir Ralph Verney's Notes on the Proceeding of the Long Pariament, and Clarendon's History of the Rebellion and Civil Wars in England. These works provided the first-hand evidence to support the general conclusions which I derived from a careful study of the secondary sources on the period.

The thesis maintains that the history of the Grand Remonstrance reflects the development of a constitutional crisis, arising from a 
fundamental disagreement, first between Charles I and the Long Parliament and subsequently between his supporters and opponents in the House of Commons, over the constitutional prerogatives of English government. That crisis, perpetuated in large measure by the Remonstrance itself, created the conditions which ultimately led to Civil War. 
THE POLITICAL AND CONSTITUTIONAL ORIGINS

OF THE GRAND REMONSTRANCE

by

JAMES S. HART JR.

A thesis submitted in partial fulfillment of the requirements for the degree of

MASTER OF ARTS

in

HISTORY

PORTLAND STATE UNIVERSITY

1979 
TO THE OFFICE OF GRADUATE STUDIES AND RESEARCH:

The members of the committee approve the thesis of James S. Hart Jr. presented May 1, 1979.

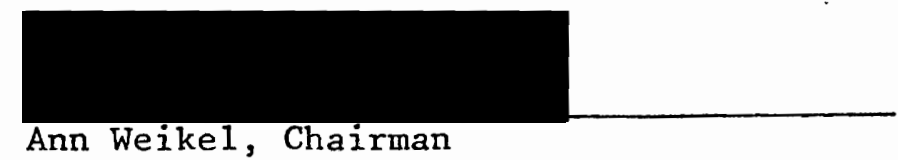

Ann Weikel, Chairman

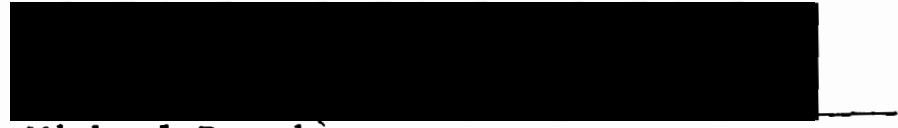

Michael Reardon

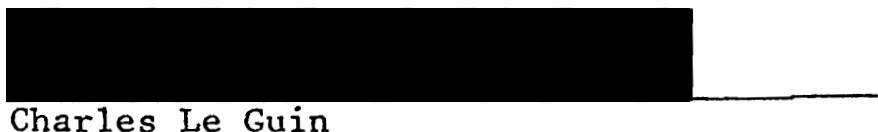

APPROVED:

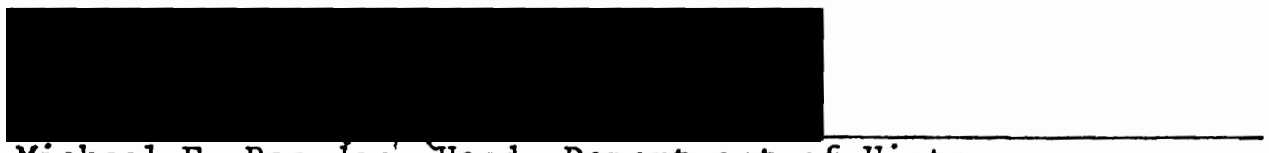

Michael F. Reardon, Head, Department of History

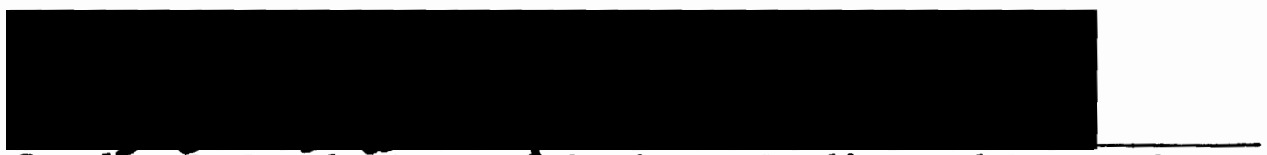

Stanley E. Rauch, Dean of Graduate Studies and Research 
TABLE OF CONTENTS

PAGE

CHAPTER

I INTRODUCTION . . . . . . . . . . . . . . 1

II AN OVERVIEW: ISSUES, AND EVENTS. . . . . . . 11

III THE LOSS OF TRUST. . . . . . . . . . . 26

IV A NEW RELATIONSHIP BETWEEN CROWN AND COMMONS • 52

V THE COLLAPSE OF CONSENSUS IN THE HOUSE . . . . 70

BIBLIOGRAPHY. . . . . . . . . . . . . . . . 93

THE SOURCES . . . . . . . . . . . . . . . . . 96 


\section{CHAPTER I}

\section{INTRODUCTION}

The history of England between 1603 and 1640 is not the history of a growing disease in the body politic, but of conflict--some of it healthy, some morbid--within a set of agreed essentials; Or rather it was this until the impatient attempt at a drastic solution on the King's behalf persuaded his opponents that the essentials were no longer agreed.

The passage above represents a brief summation of G. R. Elton's general thesis on the causes of the English Civil War and it reflects his thinking on a number of major points. Elton clearly feels, in the first place, that the Civil War was not inevitable, and that it was, in fact, improbable at any time before 1640. Secondly, he assumes that the conflict which characterized early Stuart England was, at least in part, healthy and expected of a relationship between King and Commons. The conflict was not, therefore, the manifestation of a "growing disease", and not, in any way, the reflection of a revolutionary movement in English politics. Elton's position is, instead, that the conflict between King and Commons ceased to be healthy, and became revolutionary, only when debate produced a fundamental disagreement over the essential principles of government in a constitutional monarchy.

Elton's thesis did not emerge as the result of extensive research. His field is, in fact, Tudor rather than Stuart history. His theory

${ }^{1}$. R. Elton, "The Stuart Century", reprinted in Studies in Tudor $\underline{\text { Stuart }}$ Politics and Government, Volume II, Cambridge $(1974), \overline{155-163 .}$ 
of causation is really a matter of perceptive historical analysis. Elton himself has never subjected his conclusions to the kind of authoritative investigation for which he is well known. That does not, however, diminish the importance of his assumptions. My own research in Stuart history was prompted by an interest in the very question he raises, and it has leád me to believe that his conclusions about the nature and evolution of conflict leading to Civil War, are essentially correct. The subject of this thesis was chosen in the belief that a careful study of the Grand Remonstrance would serve as a test case. The Remonstrance contains in its arguments a synthesis of the political, social, religious, and economic issues which confronted the English political nation between 1621 and 1640. It is furthermore, the only piece of comprehensive Parliamentary reform which, from its inception to its conclusion, spans the entire critical first year of the Long Parliament. It therefore serves as a constant reflection of the changing state of that Parliament in the final months prior to the Civil War, and it should, accordingly, reveal something about the causes of that conflict.

This study of the Remonstrance will show, in the first place, that the Grand Remonstrance and the conflict it eventually produced were neither reflective nor symbolic of any long term revolutionary movement either within the House or without. They were instead the result of the collapse of the unique and very specific relationship which the Long Parliament had established with Charles I. Secondly, it will demonstrate that the failure of that relationship to achieve any compromise between Crown and Parliament ultimately forced the 
House into a fatal disagreement over the constitutional principles and ecclesiastical policies which Charles had come to exemplify. This study will maintain that the Grand Remonstrance is important not because it represented the united, definitive position of any long term revolutionary movement, or because it represented the culmination of an extended debate between King and Commons over specific issues of Royal prerogative and religious doctrine, but because it represented the first occasion on which the House of Commons divided irreconcilably over a comprehensive statement of policy on those same issues. The Grand Remonstrance represented a new interpretation of the "agreed essentials", one which compelled the members of the House to take the politically uncompromising positions which lead ultimately to Civil War.

The position taken by this thesis is then a response to the general debate on the causes of the Civil War. The whole question of causation is, in fact, central to an understanding of Stuart historiography, and it has provoked considerable controversy. There have been a number of divergent approaches to the problem, but generally they reflect one of two schools of thought. The Civil war is either seen as the result of the political and constitutional struggles between the Long Parliament and Charles I, and as the particular manifestation of that relationship, or it is seen as the predictable outcome of an insoluble division between various elements of the political nation which had been developing since the reign of Elizabeth I. Therefore, it was either a specific and limited conflict which arose between a particular monarch and a particular representative body, 
or it was, in fact, the result of a long standing revolutionary movement. For each of these interpretations, the Grand Remonstrance must remain something altogether different.

The revolutionary theory of causation is essentially a reflection of the traditional Whig interpretation of history. In brief, the Whig interpretation of history begins with an established historical result, and proceeds to look for the appropriate causes. It assumes that history is progressive and that it progresses, in fact, toward a predestined goal. In the context of this debate, Whig historians have assumed that because the War eventually produced revolution, revolutionary conditions must necessarily have existed for sometime before the outbreak of war. The Civil War is examined, not as a singular historical event with its own causes and effects, but as part of a greater revolutionary movement within the English political nation. The Whig interpretation began essentially to reinterpret the conflict in terms that would demonstrate the long standing heritage of English liberalism. For Gardiner:

...the interest of history in the Seventeenth Century lies in the efforts to secure a double object--the control of the nation over its own destinies, and the liberty of the public expression of thought, without which parliamentary government is only a refined form of tyranny.

Gardiner assumed, then, that his revolutionaries were fully aware of the long term consequences of their actions. They were aware, from the outset of conflict, that the Civil War was a necessary step in a revolution needed to secure the triumph of English liberty over

${ }^{2}$ S. R. Gardiner, The First Two Stuarts and the Puritan Revolution, 1603-1660, London, $(188 \overline{8)}$, P. V. 
monarchical oppression. They were merely fulfilling England's inescapable political destiny, and the Civil War was an inevitable and unavoidable part of that process.

In the 20th century the Whig interpretation has taken on an entirely different set of assumptions, but the revolutionary principle has remained in tact. These recent historians have rejected the political and constitutional framework established by Gardiner in favor of social and economic theories of causation. In this approach, the Civil War is the natural result of developing class conflict, and a necessary part of a revolutionary struggle to establish social equality. This interpretation reflects, above anything else, the influence of the Marxian dialectic, and since it supports the notion that revolution is the result of inevitable class conflict, its adherents have sought to identify those classes and the principle elements of conflict in pre-Civil War England. The socio-economic school war initially founded by R. H. Tawney, and has survived and been supported through further contributions from Lawrence Stone and Christopher Hill. All three historians have attempted to identify a dramatic shift in the English social structure sometime between 1540 and 1640.

Tawney's first important contribution to the debate on causation came in 1941 in two major articles; "The Rise of the Gentry", and "Harrington's Interpretation of his Age". ${ }^{3}$ Both articles were essentially based on the assumption contained in Harrington's Oceana;

$3^{3}$. H. Tawney, "The Rise of the Gentry", English Historical Review, XI, (1941) 1-38, and "Harrington's Interpretation of His Age", Raleigh Lecture, Proceedings of the British Academy, XXVII, (1941) 199-224. 
the Civil War was the result of class conflict born of economic conditions. Tawney outlined two major developments; the wholesale economic decline of the Aristocracy; and the consequent ascendancy of an ambitious and economically solvent gentry. The fundamental contradiction between these economic realities, and the prevailing political conditions of Stuart England produced an irresolvable conflict.

Tawney's thesis was, in turn, elaborated by Lawrence Stone, first in 1965 in The Crisis of the Aristocracy and later, in 1972, in The Causes of the English Revolution. 4 In the former book Stone attempted to document the economic collapse of the Aristocracy and the subsequent loss of Aristocratic power and prestige, a transition which undermined the foundation of Charles I's government. Stone assumed that the weakened state of the Aristocracy left Charles I without the bastions of support needed to withstand the general assault on his authority, and his government collapsed accordingly in 1641. The latter book broadens Stone's initial theory of causation in order to take intó account important political and religious issues. For all of the additional perspective which the later work allows, Stone's central thesis remains the same. The English Civil War was the result of major social transformations which began a century before the outbreak of war.

Hill's contributions offer a somewhat more radical approach. His thesis was introduced initially in 1949 with The Good old Cause,

${ }^{4}$ Lawrence Stone, The Crisis of the Aristocracy, Oxford, (1965), and The Causes of the English Civi1 War 1529-1642, New York, (1965). 
The English Revolution 1640-1666, ${ }^{5}$ and it has been reflected in countless articles and books on social, economic, and religious aspects of the conflict. For all of his diversity, Hill has remained more or less exclusively Marxist in his interpretation. The Civil War emerges as a class conflict between a revolutionary proletariat and a feudal monarch.

All three historians assume a major shift in the basic structure of English society. In all three interpretations, as in Gardiner's, the Civil War is seen as a product of a greater and more fundamental social revolution. In this scheme, the Grand Remonstrance, as the vanguard document of Long Parliament reform, should contain the basic tenants of a revolutionary movement. It should be the final, unified declaration of opposition to the Crown, and to the social, political, and economic order which it represented.

The alternate, and more recent approach to the problem of causation entirely rejects the historical premise of the Whig interpretation. Its adherents share a common belief that the Civil War has to be examined strictly on its own terms. This school operates on two assumptions. First, it rejects the premise of a social economic, or even political revolution occurring prior to the Civil War. Secondly, it maintains that causes of the war are to be found in the political and constitutional issues which confronted the Long Parliament in its relationship with Charles $I$. In this interpretation, the Long Parliament itself defines the parameters of conflict which led to Civil War.

${ }^{5}$ Christopher Hill, and Edmund Dell, ed, The Good old Cause, The English Revolution, 1640-1660, London, (1949). 
In addition to the aforementioned articles by G. R. Elton, this "revisionist" interpretation has been supported by three major historians, all specialists in Stuart history; Conrad Russell, Paul Christianson, and J. H. Hexter. Russell really established the framework of the thesis: "Before we explain why the English Revolution happened, we should ask again if it ever did happen." 6 In an article published in 1976 entitled "Parliamentary History in Perspective", 7 Russell attempted to dispel the notion that organized opposition to the King's government existed at any point before 1629. Russel1's point was that revolution in any real sense was not only improbable, but impossible before 1640. In this Russe11 reflects the central thesis presented in Elton's earlier articles. That opinion is reffected as well in Christianson's 1976 article "The Causes of the English Revolution; A Reappraisal." 8 Christianson's article attacked the general supposition of the socio-economic school that a social revolution preceeded and provoked the Civil War. In particular, Christianson maintained that Stone's theory on the decline of the Aristocracy contradicted the political realities of the period, in which the Aristocracy was clearly a vital and functioning influence in political affairs.

${ }^{6}$ Conrad Russe11, Times Higher Education Supplement, 8 March, 1974, cited in R. C. Richardson, The Debate on the English Revolution, New York, (1977), p. 146.

7 Conrad Russe11, "Parliamentary History in Perspective", History, 61, (1976), 1-27.

${ }^{8}$ Paul Christianson, "The Causes of the English Revolution: A Reappraisal", Journal of British Studies, 15, (1976), $40-75$. 
Hexter's inclusion in this group is the result of a recent article on Parliamentary politics, ${ }^{9}$ (read after the majority of research for this thesis had been completed.) The article takes exception to both Christianson's and Russe11's respective treatments of Parliamentary opposition. Hexter recognized that the issues which brought the King and Commons into open conflict had, in fact existed, as issues, prior to the opening of the Long Parliament, and he apparently felt that both Russell and Christianson had to some extent misrepresented the situation by downplaying the importance of those issues. He did not, however, argue with the general assumptions of either Russell or Christianson. His own conclusion about the causes of the Civil War clearly reflected the revisionist position; "Beyond all contemporary and subsequent revolutions, the English Revolution was precipitated by a clash between a hereditary monarch and a representative body. "10

This is admittedly, something of an oversimplification of what amounts to a very complex historical argument. What is important is the general premise, supported by this school, that the Civil War was the result of a breakdown in the working relationship between Charles $I$ and the Long Parliament, and not the result of long term revolutionary socio-economic causes. If they are correct, the Grand Remonstrance was not the unified declaration of revolutionary opposition, but a reflection of the political components of House of Commons

9 J. H. Hexter, "Power Struggle, Parliament, and Liberty in Early Stuart England", Journal of Modern History, 非50 March (1978). ${ }^{10}$ Ibid, p. 29. 
in the fall of 1641, and a synthesis of the major issues of conflict between the King and his Commons. To date, no attempt has been made by this group to support their theory through a careful examination of the Remonstrance or any other single piece of Long Parliament reform. It is the contention of this thesis that the theory can, in fact, be supported by a careful study of the political and constitutional origins of the Grand Remonstrance. 
CHAPTER II

AN OVERVIEW: ISSUES AND EVENTS

The history of the Grand Remonstrance began effectively on 7 November 1640, and concluded some thirteen months later on 15 December 1641. It evolved in three stages. The first stage covers the period from the first week in November 1640 to the first week in May 1641. The second stage covers the period from the first week in May to the Parliamentary recess in September. The final period begins with the recess and concludes with the publication of the Remonstrance in December. These stages represent not only identifiable points of transition in the development of the Grand Remonstrance, but perceptible changes in the fundamental relationship between the Long Parliament and Charles I.

The Grand Remonstrance underwent a number of changes in its year long development:. It was initially conceived as a report to the House of Commons on the general state of the Kingdom. It was altered shortly thereafter and redesigned as a remonstrance to the king and a general petition for redress of grievances. It remained in that form to the end. Nonetheless, in the course of the development the Grand Remonstrance changed dramatically from its intended format. It changed in two ways. In the first place, it was not, as it had originally been intended, the product of a unified House of Commons appealing for redress of grievances. It had become over the months the singular 
manifesto of a given party within the House, and furthermore an instrument which did not so much appeal for reform as demand it. Secondly, for all of the intentions implied in its formal design, the final product clearly addressed its arguments to the public at large. It was no longer just a petition to King Charles. It had become an open appeal for public support for a partisan program of reform.

What these changes reflect, above anything else, is the collapse of the working relationship between Crown and Commons. The failure of Charles' leadership, and the demise of that relationship, effectively gave Parliament; or a portion. of it, the opportunity to redefine the balance of power within English government. The final authors of the Grand Remonstrance saw in this petition the means by which that balance might be readjusted in favor of Parliament and the people it served. In the end the arguments of the Remonstrance implicitly altered the inherent powers of the Crown by removing the King from his traditional position above, and at the head of, the three estates of Commons, Lords, and Clergy, and placing him instead in an altogether new equation which implied equal power to King, Lords, and Commons. That change was simply too radical a departure from historical precedent for the House as a whole to accept in December 1641, and the Remonstrance provoked a decisive and unalterable division. It is clear that, had Charles I been willing or able to deal responsibly with Parliament's appeals for reform, and had Parliament. offered a corresponding degree of compromise, the Grand Remonstrance might not have contained, as it did, imperative proposals for constitutional change. It would not than have provoked the division 
it did, and the members of the House would not have been compelled to take the irrevocable positions which eventually lead them to war.

During the initial six months of the Long Parliament the Grand Remonstrance developed in response to the two fundamental problems; the need for extensive ecclesiastical reform, and the need for a wholesale reevaluation of the King's ministerial appointments. The House responded to both of these problems with considerable debate on a number of specific and important proposals for reform and redress all of which were to affect the Remonstrance at some point. However, Parliament's inability to achieve any immediate change in... the secular and religious policies of the Crown forced the House to seek redress through the more direct means of an organized campaign of impeachment. Parliament embarked on its program of impeachment during this period primarily to accomplish change, but further to prove a basic conclusion that the major obstacles to change had been, and continued to be, the King's principle ministers. The House was operating therefore under the assumption that, by removing the offending ministers, Parliament would, at least in theory, give Charles the opportunity to operate without the undue influence of evil councillors, and to establish policies more in 1ine with Parliament's expressed wishes.

The central targets of this campaign, specifically Archbishop Laud and Thomas Wentworth, Earl of Strafford, reflect the sincerity of Parliament's belief in the premise of ministerial responsibility. Laud's impeachment was central to the whole question ot ecclesiastical reform, and his removal was, more than likely, envisioned from the 
outset of the Long Parliament. Laud was in fact impeached immediately following the first major religious debate of the session. Strafford's impeachment was more fundamentally important because strafford represented a more comprehensive symbol of Royal authority. During his long tenure in Charles' service, Strafford had been responsible for a number of major areas of Crown policy. He was also the King's most trusted and dependable adviser, and his trial was, therefore, of paramount importance, both symbolically and practically. The bill of Attainder which the House was forced to adopt after the failure of Strafford's impeachment attests to the power of its conviction, and to its willingness to put that conviction to the most conclusive possible test. Parliament was determined to bring about Strafford's demise by any means at its disposal. He was, in the eyes of this assembly, the major obstacle to a productive relationship between Crown and Commons. Consequently his trial and Attainder represent something of a watershed. It represents Parliament's final attempt to achieve major redress through established and customary channels. Having failed to accomplish any perceptible change through this initial program, the House was compelled to pursue a new, and more agressive course of action.

The Grand Remonstrance was, in large measure, the germinal stage of the impeachment process. In fact, it was initially conceived with an immediate view to subsequent impeachment trials. It was designed, first as a general committee report to the House of Commons, and then as a petition to the King, with the express purpose of assigning responsibility for major grievances where it was generally felt 
responsibility lay; with the King's ministers. The Remonstrance was to become the source from which Parliament could draw ammunition for its attacks on individual councillors. As the trials of the King's ministers progressed, it became a companion piece of reform, intimately tied to the impeachment process generally, but reflecting a more comprehensive statement of protest than any single trial might encompass. In terms of immediate Parliamentary business, the Remonstrance was not particularly conspicuous. But it continued to develop in response to the impeachment process, and in a sense, as an alternative to it. When the individual trials, and particularly Strafford's, failed to produce any concrete change in Royal policy, the Remonstrance was elevated to a position of primary importance as the major comprehensive statement of Parliamentary protest.

Strafford's execution closes the first stage of development, and effectively introduces the second. The period between the first week in May 1641 and the Parliamentary recess in September is characterized by a new relationship between King and Commons which grew directly out of Strafford's death. In the first place, the traditional targets of responsibility were no longer present. The intermediaries had been removed. Parliament was forced to conclude that responsibility for any future policy lay with the King. Charles had failed to alter his position or to address himself to Parliament's complaints, and it was therefore necessary to institute change through remedial legislation of dubious legality. The success of that legislation during the summer months was due primarily to Charles' ambivalence toward it, and to his inability or unwillingness to offer any alternatives 
to it. Furthermore, Charles had been deeply affected by Strafford's death, but particularly by the violence with which Parliament had extracted his assent to it. He felt betrayed and isolated, and he looked elsewhere, specifically to scotland, for support and relief. Charles' journey to Scotland effectively sealed forever the impasse that had grown between King and Commons. By removing himself complete1y from the nation and its pressing needs, Charles lent substantial support to the prevailing impression that his allegiance lay elsewhere. More importantly however, his eventual departure left England with a fatal lack of Royal leadership at precisely the moment it was most needed. It left Parliament with the responsibility of both establishing policy and providing leadership to the nation at large. It was a responsibility which Parliament had not previously assumed; and which it could not now provide. The unanimity which had characterized the efforts of the summer legislation suddently dissolved into a critical struggle for control of the leadership within the House itself.

The Remonstrance was affected immediately by these critical events. In the first week of August it underwent two dramatic changes which reflected the on-going developments in the House of Commons. The Remonstrance, which had, up to this point, been conceived as a single petition was subsequently divided into two petitions, one dealing with ecclesiastical abuses, and the other dealing with constitutional reform. In addition, the committee responsible for the authorship of the Remonstrance was suddenly changed, both in its size and in the representative character of its membership. Out- 
wardly at least, the Remonstrance remained what it had been; an open-ended petition for redress of grievances. Nonetheless, these two changes were to alter the scope and purpose of the Grand Remonstrance from this point forward.

The Parliamentary recess in September commences the final stage of development in the affairs of the Grand Remonstrance. The House of Commons emerged from the recess in an altogether different frame of mind than it had been in some three months earlier. The differences which had just begun to emerge immediately before the recess had grown to monumental proportions by the time Parliament reassembled. The House had split into recognizable parties, and the efforts of one of the parties, albeit a majority, to assume the leadership of the House, and thereby establish definitive secular and religious policy, had driven the House apart. The division was precipitated not only by the policies themselves, but by the very fact that those policies represented an assumption of power on the part of Parliament which historical precedent would not support. They represented a usurpation of Royal authority which a significant portion of the House simply could not accept.

In this final critical stage the Remonstrance became once again an intimate part of the workings of the House of Commons. However, the Remonstrance which emerged in November 1641 bore little resemblance to the idea conceived a year earlier. It had undergone a fundamental change of purpose. In November 1640 it had been designed as a general petition to the King for redress of grievances. By November 1641, it had become a defensive and accusative instrument for securing popular support, advocating specific solutions to specific 
problems, and assigning new rights and responsibilities to both Crown and Parliament. It had lost its impact as a collective statement of complaint on behalf of a united House of Commons. In its final form, it reflected the arguments of only half of the House. By bringing the Grand Remonstrance to a vote, its proponents guaranteed that Parliament would divide against itself.

If the Grand Remonstrance reflects anything about the Long Parliament it is the fact that the eventual breach in the House of Commons was caused by religious and political differences which developed during its tenure and within the context of specific issues. The division was neither predetermined, or for that matter perpetuated by any long-standing divisions between social classes or economic interests present within its ranks when it assembled on November 3, 1640. Extensive research on the membership of the Long Parliament has successfully dispelled that notion. ${ }^{11}$ The positions taken by members of this Parliament, when they had to be taken, reflected a cross section of its original membership which defied any definite or pre-existing pattern. The essential political components of this assembly, as with previous Parliaments, were, predominantly, members of the landed class, members of the bar, and merchants. But there was apparently nothing about any of these three distinguishable classes which would have naturally compelled one of its members to take a given side in the constitutional

${ }^{11}$ I am indebted for information on the membership to Mary F. Keeler, The Long Parliament, Philadelphia, (1954) and D. Brunton and D. H. Pennington, Members of the Long Parliament, London, (1968). 
debates of the period. For all of the controversy surrounding the economic and social mobility of the period. For all of the controversy surrounding the economic and social mobility of the period, the evidence indicates, that in terms of background:

...Royalist and Parliamentarian...were very much the same; that the greater and lesser gentry were not on different sides; that it made no difference whether a member belonged to an "old" or a "new" family; that merchants and lawyers were to be found on both sides, and in such proportions as to make it doubtful whether there was any hostility to the king among provincial merchanfs, and certain that there was none amongst the lawyers.

There are, of course some singular things about the Long Parliaments's membership. It was, by normal standards, an unusually young and inexperienced assembly. Fully half of the membership was under the age of forty, while only one fifth were over the age of fifty. In addition, the majority of the Long Parliament's members had no previous parliamentary experience whatsoever. Only 203 of the original 507 members had sat in Parliament before 1640, and only 140 of those 203 has sat as recently as the Parliament of 1628-29. 13 Previous parliamentary experience may, in fact, have influenced political affiliation once Parliament convened. Of the 203 members with previous experience, only 75 eventually sided with the Crown and the remaining 128 took the Parliamentary cause. 14

In any case, it is clear that all of the members who came to the House of Commons in November 1640, came with a common

12 Brunton and Pennington, op. cit. P. 19.

${ }^{13}$ Brunton and Pennington, op. cit. p. xii.

${ }^{14}$ Ibid, p. 15. These figures exclude those for the short Parliament. 
understanding of the major problems at hand. The important constitutional stuggles of the Parliament of 1628-29, and those of the ensuing eleven years without Parliament, weighed heavily on the returning members. The issues reflected in the Petition of Right, and subsequently in such things as the Forced Loan, Ship Money, and in Laud's ecclesiastical innovations, remained, for the most part, unresolved. Membership in the Long Parliament represented, from the outset, a major challenge to prospective members. ${ }^{15}$

The elections themselves reflected that understanding. The order for issuing writs provoked a number of heated contests as both friends of the Court, and members of the nominal opposition brought significant pressure to bear on individual elections. In the end, thirty-eight of the original elections were challenged and required arbitration by the House itself. 16 The opposition eventually gained a majority in the House and then reinforced that majority by establishing control over the important Committee for Privileges which determined the outcome in disputed elections. While it may not be altogether true, as Clarendon claimed, that "no rule of justice was so much as pretended to be observed....,"17 the opposition's majority on the committee was considerable and the effect was telling. It would be misleading, and, in fact, inaccurate to leave the impression that the House of Commons was divided, evenly or otherwise,

${ }^{15}$ See Discussion of election of John Clotworthy, p. 31. ${ }^{16}$ Keeler, op. cit. p. 7 .

${ }^{17}$ Hyde, Edward, Earl of Clarendon, The History of the Rebellion and the Civil Wars in England, Vol. 1, p. 228 . 
in the fall of $1640 . .^{18}$ It is important to remember that subsequent events would show the House displaying surprising unanimity on a number of major proposals for reform. Strafford's impeachment is an obvious case in point. In fact, the complexity of issues confronting the Long Parliament produced equally complex and shifting configurations of political allegiance, at least until the fall of 1641 . For all of the various components involved, the House was essentially composed of three identifiable groups. ${ }^{19}$ on the one hand were the ardent supporters and champions of King and Crown. On the other were followers of men such as John Pym, John Hampden, and Nathanie1 Fiennes, who together constituted an ever growing nucleus of committed opposition, and who presumably had long standing arguments with Crown policy. In the middle were a group of political moderates, supportive of reasonable and judicious reform, but resistent to comprehensive or violent change. This configuration lasted, despite a number of challenges to it on a number of specific issues, until the end of the summer of 1641. At that point pressure from both sides forced the collapse of the middle constituency, and the subsequent formation of the two parties of the Civil War era.

${ }^{18}$ The whole question of opposition and political parties in the House of Commons has been subjected to considerable historiographical controversy. Lawrence Stone, for instance sees the House united in opposition to the King, and therefore sees only one party in operation, that of the opposition. At the opposite extreme, Conrad Russell maintains that the House was anything but unified, or organized, and certainly not in open opposition to the Crown. Others, like Perez Zagorin, maintain that the House supported two parties, one representing King and Court, the other an organized Country opposition. I have used the composition outlined by Keeler because I think it reflects the most accurate picture of the conditions in the Commons.

$$
{ }^{19} \text { Keeler, op. cit. p. } 11 .
$$


The events and arguments which developed during the critical twelve months prior to the Civil War, and which ultimately formed the substance of the Grand Remonstrance, reflected, to a greater or lesser degree, two fundamental problems; the need for basic religious reform; and the need to establish some sense of control over the principle architects of Crown policy. Both issues contain a number of complex and inter-related problems.

The need for religious reform, and the arguments which it produced, reflected not so much basic questions of theology as a general concern with a problem of authority in both religious practice and church government. The basic conflict between the Laudian religious practice imposed by Crown policy and the strictures of Puritanism was certainly a real one. But the conflict was derived equally from the method of imposing those innovations as from the matter. Laud's repressive policies represented a specific relationship between Crown and Church summed up in James' I famous aphorism "No Bishop, No King". The Stuart Dynasty had, from the beginning, looked to the Church to support its claims of Divine Right as the basis for Royal prerogative, just as the Church looked to the Crown for official sanction of its policies, and for protection from its reformminded critics. At the height of the Laudian campaign, civil and religious authority were, for all intents and purposes, one and the same. "Hence, a position was created in which the puritan found that any opposition to the Church was regarded as sedition at Court, and any criticism of the monarchy was denounced as blasphemy in the pulpit." 20

${ }^{20}$ Godfrey Davies, The Early Stuarts, Oxford, (1959), p. 71. 
In terms of Church government the major point of contention, and the principle target of Puritan opposition, certainly during 1640 and 1641, was the Episcopacy itself. At the heart of the issue was, again, the fundamental question of authority. The entire hierarchy of the English Church, from Archbishop to prelate, was founded on the basic premise of apostolic succession, and therefore; on a claim of Divine Right which the puritan mind simply could not support. The Episcopacy might well have come under far less criticism had it not used that claim as the authority under which it imposed extravagent ceremonial innovations which, for the greater part of the puritan constituency, represented a regressive trend toward prereformation religious observance. Finally, the antagonism toward the Episcopacy was aggravated by the increasingly influential presence of the bishops in secular offices, and hence, in the formation of secular policy. It was this situation which compromised the clergy's claim to an apostolic mission, and which reinforced, at the same time, the prevailing impression that religious and secular authority were indistinguishable.

The problem of establishing control over the authors of Royal policy represented the cornerstone of opposition to the Crown. It was manifest in a concerted and deliberate attack on the King's ministers which began with the initial debate of the session and continued through the final vote on the Grand Remonstrance. Parliament assembled in November 1640 clearly intent on reform. However, the pursuit of reform was conducted, at least initially, within the context of a traditional belief in the inculpability of the King. 
In other words, Parliament was forced to make a clear distinction in its criticism between the King's person and Crown policy. In spite of the political atmosphere at the opening of the Long Parliament, The House was still operating on the premise that the King could do no wrong. This was not simply a political gesture to protect the King from public accusation. It was an operating political principle. In its full dimensions the concept embodied three further principles which governed the relationship between the King and his ministers. It assumed, in the first place, that the king could not act on his own accord, but only through his servants; it asserted that a minister should refuse to carry out any Royal command that was, either by common understanding or tradition, considered illegal; and it denied protection to an adviser who plead the King's command as a defense for a subsequent illegal act. "Together, these three principles free the King from all legal responsibility for the acts of his government, and places the responsibility on his ministers."21

It is impossible to minimize the importance of this concept to the members of the Long Parliament. The premise of ministerial responsibility was, in a sense, the vanguard of Parliamentary activity. It allowed the House to fix responsibility for its grievances, and to thereby establish the general cause of unrest. It was to pretext on which the members proceeded to punish those responsible by instituting the program of impeachment, and it was the

${ }^{21} \mathrm{Clayton}$ Roberts, The Growth of Responsible Government in Stuart England, Cambridge, (1966), p. 8. Roberts book offers a detailed and careful study of the growth of impeachment, as a parliamentary device in early stuart England. 
principle from which Parliament sought to reestablish a healthy and productive relationship with the Crown.

These two problems, the issue of evil councillors, and the need for ecclesiastical reform, together provided the framework of conflict from which the Grand Remonstrance developed. Both issues reflect immediate and fundamental problems in the relationship between Charles I and the Long Parliament. As that relationship continued to deteriorate during the initial twelve months of the Long Parliament, the Grand Remonstrance became correspondingly more important. When it finally came to fruition, the Remonstrance was an indication that that relationship had collapsed altogether. 
...The same men who six months before were observed to be of very moderate tempers, and to wish that gentle remedies might be applied without opening the wound too wide...n 22 talked in another dialect both of things and persons...

Clarendon's description of the collective temperament of the Long Parliament in November 1640 was an accurate one. Moderation had, in fact, given way to a new, more insistent call for reform. The members of the Long Parliament were determined to establish an effective course of action that would ensure the redress of their grievances. During the initial six months Parliament devoted its attention to a number of different proposals for reform. But, all of its efforts, in a sense, reflected a clear understanding of one fundamental problem: the need to remove the King's principle ministers from their appointed positions of influence. Accordingly, this initial period saw the Long Parliament direct the greater part of its energies toward a central campaign of ministerial impeachments. It was this campaign which gave birth to the Grand Remonstrance, and which initiated the collapse of Parliament's working relationship with Charles I.

The general cry for reform in the opening months allowed the opposition to take the initiative in directing Pariamentary activity. That direction came primarily from John Pym. Pym had served his 
political apprenticeship in six previous parliaments, beginning in 1621. He had, by 1641 , established himself as a respected, experienced politician. It is important to remember, in view of the developments of the ensuing months, that Pym was not, by any definition, revolutionary or even radical, at least in the context of the initial parliamentary debates. He emerged as the leader of a nominal opposition that was essentially conservative in its outlook. It opposed innovation rather than supported it. Pym and his immediate allies sought, at least in the beginning, to restore and preserve order, not to disrupt it with violent change. In fact, Parliament was to be the key to preservation. It was "...the most conservative force in existence..., the guardian of the old religion and the old law against the new fangled nostroms of Strafford and Laud." 23

Nonetheless, Pym was not able to control the House from the outset, at least not in the sense that he was to control the House some months in the future. ${ }^{24}$ Gardiner's view, is perhaps the most accurate. He described Pym as "the directing influence of a knot of men who constituted the inspiring force of Parliamentary opposition."25 Pym's "knot" of political lieutenants included John Hampden, Nathaniel Fiennes, Henry Vane Jr., Willian Strode, Walter Earle, John Clotworthy, and Denzil Holles. Hampden, Holles, Earle and Strode,

${ }^{23}$ Samuel R. Gardiner, History of England, Vol. IX, AMS Press, New York, 1965, p. 223.

${ }^{24}$ Wallace Notestein, The Journal of Sir Simonds D'Ewes, Yale University Press, 1923, p. 4 . Notestein implies that Pym took control of the House immediately. The full scope of Pym's career is covered in two separate studies: S. Reed Brett's John Pym, John Murray, London, 1940 , and J. H. Hexter's The Reign of King Pym, Harvard University Press, Cambridge, 1941.

${ }^{25}$ Gardiner, 오. cit., p. 223. 
had, like Pym, served in the House since the $1620^{\prime} \mathrm{s}$, and all four had suffered arrest and imprisonment for their political convictions. 26 Fiennes, Vane, and Clotworthy were making their debut in the House in 1640 , but had inherited, either from experience or family background, a similar political persuasion. These men, together with Pym, provided the leadership and organization for the growing opposition in the House.

Pym launched the "conservative" campaign in his opening speech on 7 November. He carefully described the basic problems of the realm and outlined his proposed solutions. In some measure, the speech represented the political platform of the opposition movement. D'Ewes' Journal gives a full account of the speech which begins with the note; "Mr. Pymme moved for a reformation etc., finding out authors and punishments of them." 27 The main thrust of Pym's speech was a description of "a design to alter the Kingdom both in Religion and Government." 28 Rushworth's account is somewhat more revealing. It demonstrates Pym's clear understanding of the source of the grievances at hand. "The King can do no wrong. The Law casts all miscarriages upon the ministers."29 Pym's miscarriages were extensive,

${ }^{26}$ Holles and Strode were imprisoned for refusing to adjourn at the close of the Parliament of 1628-29. Hampden and Earle had been imprisoned, along with Strode, for refusal to comply with the Forced Loan. The full political history of these individuals is contained in Keeler, op. cit., and in the Dictionary of National Biography.

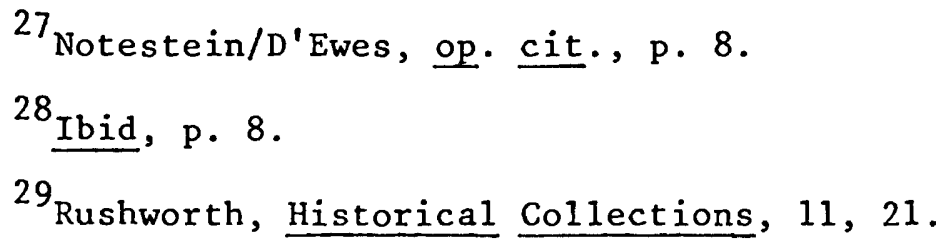


but generally fell into one of three categories, "1) Some against the Priveledge of Parliament. 2) Others to the prejudice of Religion. 3) Some against the Liberty of the Subject." 30 These three categories were later to appear, in somewhat different form, as a general areas of complaint in the Grand Remonstrance.

The first category was devoted, in Pym's speech, to the suspension of liberties in the House of Commons, and to the "abrupt dissolution of Parliament." 31 The second dealt, for the most part, with the ceremonial innovations in the Church, and with the Church's subsequent efforts to impose uniformity in religious practice. In the third and last phase of the speech, Pym gave a predictable account of the abuses of the last eleven years, and of the infringements on the rights of the subject through Ship Money, Monopolies, Tonnage and Poundage, and the activities of the High Court of Star Chamber. In all of this Pym never lost sight of his major complaint: the King's evil councillors. Nor did he abandon his central theme that "grievances were as hurtful to the King as to the subjects by interrupting their communion." 32 In the end, his purpose was made strikingly clear. "Now the remedies, and removing these grievances consist of two main branches; in declaring the law where it is doubtful; and in providing for the execution of the Law where it is clear."33

The attention given to Pym's speech in contemporary accounts testifies to its importance. But it is important for more than just the

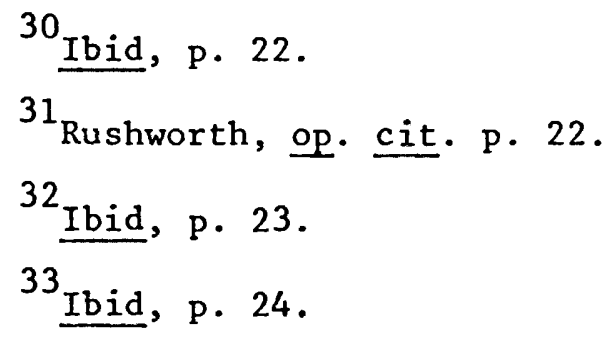


fact that it demonstrates Pym's clear understanding of current problems. In fact, the speech clarifies his thinking on three major points: It demonstrates Pym's firm belief in the premise of ministerial responsibility; it indicates that he clearly recognized the importance of maintaining a healthy relationship between King and Commons; and finally, it demonstrates that he was committed to remedial measures which would at all times reflect established legal precedent. The speech reflects, on the whole, a basic conservatism in Pym's political outlook at this stage. His thinking on all three points was to change drastically in the next year, and this speech is therefore, important as a means to evaluate Pym's subsequent political development.

For contemporaries, the impact of the speech was immediate and its implications were unmistakable. ${ }^{34}$ It was followed, three days later, on the 10 th of November, by a major address on the state of the Kingdom by George Lord Digby. Digby's speech would not have been particularly important, or even particularly noticeable had it not contained a highly significant proposal. 35 Rushworth's account, (erroneously dated on the $9 \mathrm{th}$ ), makes clear that Pym's theme had been carried forward by Digby. After a similar recitation of the grievances of the day, Digby proposed:

${ }^{34} \mathrm{Clarendon}$ was, at least in retrospect, an exception to the rule. He saw Pym's speech as a "specious commendation of the Nature and goodness of the King, that he might wound him with less suspicion" Clarendon, op. cit., p. 223. He also misdates Pym's speech on the 11th instead of the 7th. Both D'Ewes' Journal (Notestein/D'Ewes p. 7) and Rushworth (p. 27) place the speech on the 7 th.

${ }^{35}$ The D'Ewes Journal omits any mention of Digby's speech entirely. In fact, from the $6 \mathrm{th}$ to the 19 th of November $1640 \mathrm{D}$ 'Ewes was not in attendance in the House and the Journal was written by one John Bodville. This may explain the ommission. (Notestein/D'Ewes p. 1 n.1). 
... a way to remedy, by seeking to remove from our Sovereign such unjust judges, such pernicious councillors, and discontented Divines as have...by their wicked practices pr $\$ \overline{6}$ voked aspersions upon the graciousest and best of Kings.

Digby's use of the appropriate graphic quotation was especially telling:

Let me acquaint you, Mr. Speaker, with an aphorism in Hippocrates no less authentic, I think, in the Body Politic than in the Natural; thus it is, Mr. Speaker, Bodies to be thoroughly and effectually purged, yoy $37^{\text {must }}$ have their humors made first fluid and moveable.

He then went on to make his historic motion:

...That a select Committee may be appointed to Draw out of all that hath been represented, such a REMONSTRANCE (capitalization Rushworth's) as may be a faithful and lively representation to his Majesty of the deplorable estate of the Kingdom, and such as may happily discover unto his clear and exellent judgement, the pernicious authors of it.

Digby's speech and motion gave birth to what was to become the Grand Remonstrance. It is a reflection of the conservative temperament of the House at this stage that Digby's motion had to undergo a number of important alterations before it was passed. Certainly the House was intent on reform, but, as yet, it was not willing to support a general condemnation of the King's government, at least not in the form of a petition to the King himself. The tone of Digby's motion was simply too violent. In the end, the House removed Digby's accusative language and replaced the petition with a general declaration to the House. As it was finally adopted, the motion appointed a Committee of Twenty Four which was:

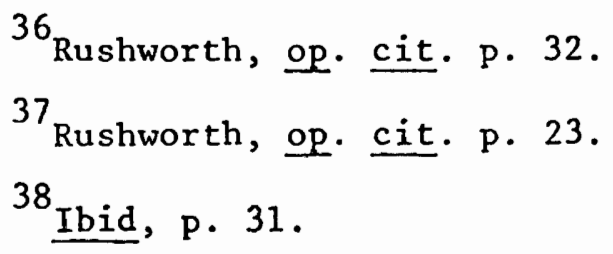


to draw out of that which hath been presented...to this House sum such way of Declaration as may be a faithful 3 epresentation to this House on the Estate of the Kingdom.

The change was significant. Digby's motion was addressed to the King and would undoubtedly have produced a direct confrontation between Charles and Parliament. The Declaration was instead addressed to the general membership of the House. It would serve as a preface to any formal appeal to the King. A majority of the House apparently felt it more prudent at this stage to seek a consensus within the House itself before making any direct assault on Charles and his government .

Despite the changes, however, it is clear that the impression left by Digby's motion was not lost on the membership. In his memoirs Lord Mandeville described the event in langauge all too similar to Digby's original motion:

The grievances of the Kingdom having been fully enumerated and declared... it was conceived by them to be the most certain way, and the most consistent with the duty and allegience of the subjects to fix their complaints and accusations upon the Evil Councillors, as the immediate actors in the tragical miseries of the Kingdom... Therefore it was resolved that the Whole House of Commons such a Remonstrance as might be a faithful and lively representation to His Majesty of the Deplorable Estate of the Kingdom, and might point out to Him those that were the most obnoxious and lyable to censure.

Both the role assigned to the Committee of Twenty Four and its membership are extremely important. Significantly, the final motion appointing the Committee specified that "any other committee that shall find anything fit for this business shall report it to the House;

39 Journal of the House of Commons, Volume 11, p. 25. ${ }^{40}$ Notestein/D'Ewes op. cit. p. 22. Note. 
that the House may...recommend it to this Committee, to be from them presented to this House." 41 The motion indicates two things; that the scope of the committee's assignment was to be as broad and comprehensive as possible; and that it was to have a direct and immediate relationship to the other committees of the House. The Committee was itself, predictably, composed in favor of the opposition, with a number of immediately recognizable members of the reformist opposition in attendance, notably, Pym, Digby, Earle, Clotworthy, St. John, Hampden, and Selden. There was not a single member of the King's group of loyal supporters, a Hyde or a Falkland, to be found. The Committee and its Declaration were meant to form a foundation upon which specific efforts of reform could be built. However, it did not work out in exactly that way, at least initially. The commencement of proceeding against the Ear1 of strafford overshadowed the Committee's assignment, and, in some measure, retarded the progress of the Remonstrance. Nonetheless, it is clear that the two developments were closely related. 42 The House moved against Strafford the day following Digby's motion on evil ministers. In addition, six of the eight members of the new Select Committee assigned to bring charges against strafford, were also members of the Committee of Twenty Four appointed the day before. Those members

\section{${ }^{41}$ Commons Journa1s 11 p. 25.}

${ }^{42}$ Gardiner completely overlooks this entire episode in the History, mentioning neither Digby's speech or the motion for the Remonstrance. Gardiner apparently felt that Strafford's impeachment was far more important than the long range effects of Digby's motion. 
were Pym, Hampden, St. John, Earle, Digby, and John Clotworthy. 43 If nothing else, the Select Committee attests to the organizational abilities of the opposition. It also clearly reflects the opposition's committment to immediate reform. Digby's motion and its accusations against evil councillors had, in fact, failed to pass the House. The opposition had been unable to enlist the necessary support of the Commons for a general condemnation of the King's ministers. It therefore moved to impeach one of them on specific charges.

Nonetheless, the House's attention was not diverted from the Remonstrance for very long. During the next two and a half weeks the momentum created by Strafford's impeachment eventually revived interest in the general provisions proposed for a Remonstrance. On 1 December the House reversed its earlier decision and replaced the Declaration with the original Remonstrance conceived in Digby's motion of 10 November. "The preparing of a humble Remonstrance to His Majesty....are referred to the Committee of Twenty Four; formerly named, to draw up a represenatation of the Estate of the Kingdom." 44 The Commons' decision changed the audience of the

${ }^{43}$ Clotworthy's membership on the Select Committee, and in the House itself, indicates that some kind of attack on Strafford was anticipated before Parliament convened. Clotworthy was Irish, an outspoken critic of Strafford's tenure in Ireland, and was related through friendhip and marriage to Pym. He had not sat in the House before 1640 and eventually sat for a borough under the direct control of Pym's patron, the Earl of Bedford. (Hugh F. Kearney, Strafford in Ireland, Manchester University Press, (1959), p. 199). Clarendon Rèbel1ion,p. 224.) was probably correct when he maintained that clotworthy had been "by contrivance and recommendation of some powerful persons returned..so he might be enabled to act his part against the Lord Lieutenant."

${ }^{44}$ Commons Journals, 11, 43. and Rushworth, op c cit., p. 71. 
Remonstrance once again. While there is no direct evidence from contemporary sources to account for this change, it seems logical that the evidence gathered in the proceedings against strafford, and in the petitions which the Committee presumably must have acquired up to this point, may well have created sufficient pressure to convince the House of the need for a formal appeal to the King. Whatever the reasons may have been, the change of address was a major alteration which changed forever the purpose and tone of the Grand Remonstrance. The attention focused on the Committee's work was further diverted by two major events in late December. The first was the presentation of the London Petition on Episcopacy, later known as the Root and Branch petition, on December 11th, and the other was the impeachment of Archbishop Laud on the 18th. The London Petition was presented to the House by Alderman Pennington and carried the signatures of 15,000 Londoners calling for the abolition of the Episcopacy. As justificaton it contained "A particular of the manifold pressures and grievances, caused, practiced, and occasioned by the Prelates and their Dependents:"45 Clarendon, of course maintained that "it was a strange uningenuity and mountebankery that was practiced in procuring these petitions", 46 and that its supporters had, in fact, later substituted an altogether different and more violent petition for the one which had been signed by the 15,000 Londoners. This is probably unlikely, especially since the Petition was accompanied to Westminster by a supportive crowd of its original signatoriès.

$$
\begin{aligned}
& { }^{45} \text { Rushworth, op cit. p. } 93 . \\
& { }^{46} \mathrm{Clarendon,} \mathrm{op} \text { cit. p. } 271 \text {. }
\end{aligned}
$$


The House, at least, did not contest the authenticity of the Petition, and proceeded to debate the whole subject. In the end, the House decided to postpone further debate for a week, (after which it was postponed for a considerably longer period), and instructed that copies be made for the members of the House and "none else."47

The introduction of the Root and Branch Petition was a vitally important occasion. It was, according to Gardiner at least, "the first time that the House had been seriously divided."48 It was also the first time that a major proposal for religious reform had been brought before the House for debate. The Root and Branch Petition was to become, in February, a House initiated bill of the same name, and further, the foundation and focus of all of Parliament's subsequent struggles over religion.

The effect of the Petition was in some measure, reflected in the speed with which the House moved to impeach Laud. For the entire week following its presentation, debate in the House was largely devoted to religious issues. The main thrust of the discussion centered around the ecclesiastical policy established by Convocation in its Canons the previous spring. The outcome of the debate was a resolution passed on the 16th of December which declared:

These Canons and constitutions ecclesiastical...do contain in them many matters contrary to the King's prerogative, to the fundamental laws and statutes of the Realm, to the Right of Parliament, to the property and liberty of the subject, and 4 matters tending to sedition and of dangerous consequence.

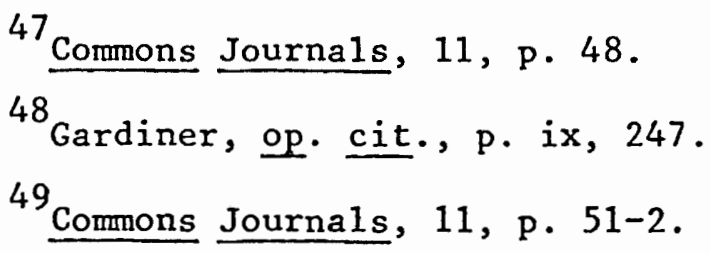


There are two key phrases in this resolution. The first is the one referring to the rights of Parliament. The Canons had been passed without the prior approval of the House, and that became the principle issue of debate. Parliament was asserting that right of approval for the first time in this resolution. In the words of the Root and Branch petition, the Commons was not going to allow Convocation and its Canons to continue "spoiling both the King and Parliament of their power."50 The Canons were therefore declared illegal. The second reference, to "matters of sedition", was a tacit recognition that, having passed illegal acts, the members of Convocation, and particularly the work's principle author, would be subject to an accusation of treason. In the words of Harbottle Grimstone, Laud was declared to be "the root and branch of all our miseries," 51 and summarily impeached on the $18 \mathrm{th}$.

Parliament had progressed to an interesting point by the beginning of 1641 . It had succeeded in removing the two principle architects of Royal policy from their respective spheres of influence, and had established a tentative basis for the discussion of religious reform. In addition to its success on specific issues, the Commons had at least established its intent to pursue a formal declaration on the state of the Kingdom. In terms of immediate visibility, the Remonstrance was overshadowed by specific projects in the House. Nonetheless, there is little question that the work of the Committee was proceeding or that the House considered its work fundamentally

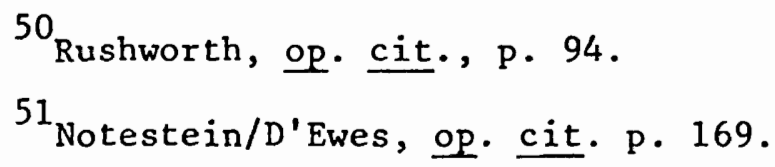


important. The Commons had successfully removed Laud and Strafford, for the time being. But there was no assurance that either impeachment would be successful, or that, if they were, the result would be a drastic change in Royal policy. Therefore, the Remonstrance became singularly important as an alternative approach, as a collective statement on the general state of the Kingdom, and as a comprehensive appeal for reform.

The effect of the Common' action up to this point is, in some measure, reflected in Charles' response to it. The King's speech on the 23rd of January makes clear that, at least in terms of reform, there was little common ground between Charles and the Long Parliament. Charles began his speech with an attempt to place the political issues at hand in perspective:

...There are some men, that more malisciously than ignorantly, will put no difference between reformation and alternation of government; ... Now I must tell you, that I make a great difference between reformation and altefztion...tho $I$ am for the first, I cannot give way to the latter.

Charles wanted to make a clear distinction between what he considered acceptable reform, and what he considered completely unacceptable alterations of ecclesiastical and civil government. He was prepared, in the name of reform to "reduce all things to the best and purest time, as they were in the time of Queen Elizabeth." 53 He agreed to rid the Church of all innovation and consented, in principle, to restrictions imposed on the temporal authority of the Bishops, providing that Parliament could show him that that authority was inconvenient

${ }^{52}$ Rushworth, op. cit. p. 155 .

${ }^{53}$ Ibid, p. 155 . 
to the state. He also agreed to relinquish any sources of personal revenue which had been, or might be, declared illegal. That was as far as he was prepared to go.

Charles then made it equally clear that he could not support either the abolition of the Episcopacy or the removal of the Bishops from the House of Lords, proposals which had been discussed in the House in connection with the Root and Branch Petition. Nor could he endorse the provisions of the Triennial Act which Parliament had passed four days earlier. These proposals amounted to serious alterations of government which he would not countenance. Clearly, Charles felt that Parliament was attempting to usurp his prerogative powers, and to curb the inherent authority of the Crown.

The King's speech left the House completely dissatisfied. Charles' concessions were purposely left generalized and vague. His promise to restore the Church to an Elizabethan standard could only have been mildly reassuring to a House obviously intent on far more sweeping reform. His willingness to relinguish his sources of personal income depended on their being declared illegal. Legal precedent established with the Ship Money case, and with the case on Impositions, made that an unlikely possibility. Charles, and certainly the membership of this Parliament, clearly understood that. His outright refusal to consider either the Triennial Act, or any of the religious petitions before the House, left the Commons with the distinct impression that Charles was unwilling to cooperate at all. D'Ewes Journal contains an entry for 23 January which demonstrates the reaction of the House. "The speech filled most of us with sad apprehensions of future evils, 
in case His Majesty should be irremovably fixed to uphold the Bishops in their wealth, pride, and tyranny." 54 Charles' uncanny ability to misread the temperament of the House, and to provoke them into a defensive reaction was again the order of the day. For all of the polite concessions which the speech implied, its tone was both condescending and threatening. It only exascerbated the already hostile temper of the House, and only succeeded in reinforcing the opposition's commitment to pursue more aggressive reform. Accordingly, the next three months saw the House devote the greater part of its energies to two major projects; a revival of debate on the issue of Episcopacy, and the conclusion of its efforts to dispose of Strafford. The debate on the Root and Branch Petition was revived on 8 February, 1641. The debate had been postponed from the originally scheduled session on 17 December, probably because the initial debate clearly indicated that the issue would provoke a major division in the ranks, at precisely the time when a public image of unity in the House was most needed. The House was compelled to revive the debate in February because of the implications of the King's address, and because of the presentation of yet another proposal of ecclesiastical reform, known as the Ministers Petition. The Minister's Petition arrived in the House on the $8 \mathrm{th}$. It differed from the Root and Branch Bill in one major aspect. It did not advocate the abolition of the Episcopacy. It proposed instead, that the Bishops be retained, but suggested that they not be allowed to hold secular offices. The debate on the 8 th and 9 th arose essentially over whether the House

${ }^{54}$ Notestein/D'Ewes, op. cit. p. 281. 
should commit one, or the other, of the bills, and, by extension, whether it should, in doing so, support reform or abolition of the Episcopacy. Rushworth's entry for the 9 th is extensive and begins with an uncharacteristically colorful note:

There were these two days great and tedious Debates in the House of Commons concerning Episcopal Government; Divers opinions there were, some for the reformation of the Bishops others to have them quite taken away.

During the course of the debates, the whole subject of

Episcopacy transcended the problem of religious observance, and came to rest on the fundamental question of the relationship between civil and religious authority. The debate reflected a challenge to the whole foundation upon which all authority rested:

In the mass outcry against Episcopacy, its defenders scented something dangerous in the air; a rising breeze of popular initiative in religion, an attraction to the spirit of innovation; an impulse toward a church order likely to be less effective than the Bishops in buttressing the existing regime of privledge.

The issues at stake were clearly seen in exactly these terms, and the debate itself produced a decisive split in the opposition ranks. Such normally sympathetic members as Lord Digby and Nathaniel Fiennes parted company over the whole question of Church Government. Digby saw the petitions themselves as a fundamental threat to the central authority of both ecclesiastical and civil government. Fiennes, on the other hand, saw the relationship between secular and religious authority as dangerous in itself, at least under the conditions which existed in the winter of 1641. In either case, the question at hand

${ }^{55}$ Rushworth, op. cit. p. 170 .

${ }^{56}$ Perez Zagorin, The Court and the Country, New York, (1971), p. 236 . 
represented something more than just a debate on the reform or abolition of the Episcopacy.

Digby, in an extended speech, spoke more of the source and manner of presentation of the Petitions than of their contents:

I am confident that there is no man of judgement that will think it is fit for a Parliament under a Monarchy to give countenance to irregular and tumultous assemblies of people... There is no man of the least insight into Nature or History but knows the Danger, when either true or pretended stimplation of conscience hath once given a Multitude Agitation.

Digby's point of view was also reflected in the response of Benjamin Rudyerd, "But let us well bethink ourselves, whether a popular Democratical Government of the Church...will be either suitable or acceptable to a Royal Monarchical government of the State." 58 The opposing view was presented in a brilliant speech by Fiennes:

There is a constant hate and feud between the Ecclesiastical State and the Civil, between Canon law and the Common Law... arising from the disproportion and dissimilitude which is between the Civil and Ecclesiastical governments... Until the Ecclesiastical government be framed something of another twift and be more assimilated into the Commonwealth; I fear the Ecclesiastical government will be no good neighbor to the Civil, but will be casting its Leaven into it to reduce that also to a sole, Absolute, and Arbitrary way of proceeding.

The gulf between the two positions was wide, and the opposition's fears about the divisive nature of the religious issue had been well founded. The debates provoked a decidedly conservative reaction from members, and, in fact, fromsome leaders of the opposition. On the whole the debates reflect the fact that the majority of the House was

${ }^{57}$ Rushworth, op. cit., p. 171. Rushworth capitalized the last sentence in order to emphasize its importance.

58. Ibid, p. 183.

59 Ibid, p. 179. 
not in a revolutionary frame of mind at this stage of the Long Parliament's proceedings. The challenge to Church government had come to represent a greater challenge to government authority as a whole, and the House reacted, at least for the moment, by reaffirming its support for the existing order. In the end the Commons committed both the Root and Branch Petition and the Minister's petition to the Committee of Twenty Four. D'Ewes account describes the state of the House at the end of the debate:

....And yet this order did not pass without the dissent of manye; before it was allowed. This being passed and ratified we fell upon a new debate; to what committee should this be referred; and at last it was agreed that it should be referred to the Committee of Four and Twenty.

The division needed to commit the petitions caused, interestingly, an almost even split in the House, 180 for and 145 against. 61 The fact that the petitions were ultimately referred to the Committee of Twenty Four reflects its growing importance in relation to the general scope of House business. The House was clearly not trying to bury this difficult issue. In fact, the Commons proceeded immediately to name six new members to the Committee to assist in handing its new assignment. The new members were Thomas Roe, Denzil Holles, Geofferey Palmer, Nathaniel Fiennes, and Henry Vane Jr. Two of these members, Fiennes and Vane were stout supporters of Pym and were committed to radical ecclesaistical reform. If anything the outcome of the debate and the referral of the petitions reflect the efforts of Pym and his immediate associates to consolidate all major issues under the author${ }^{60}$ Notestein/D'Ewes p. 342.

${ }^{61}$ Commons Journals, $11, \mathrm{p} .47$. 
ity of a single committee on which they had a sizable majority. Pym obviously felt that this committee would play a crucial role in the development of the opposition's program.

Having delegated responsibility for the religious petitions to the committee of Twenty Four, the House turned its attention toward the proceedings against the Earl of Strafford. Both for its immediate results, and for its long term consequences, the trial of Strafford, which began on the 22nd of March, was the pivitol event in the first six months of the Long Parliament's history. The opposition had staked everything on Strafford's removal, both because of his importance as a symbol of misguided influence at Court. His trial, and the charges brought against him, represented a significant advance in the strategy and political mood of the opposition. The whole crux of Strafford's impeachment lay with his opponent's ability to prove that the Earl had, in fact, committed treason. This represented a major challenge; it required not only a list of specific charges, but a redefinition of the whole concept of treason itself.

There were twenty eight charges leveled at Strafford, the majority of which concerned his tenure as Lord Lieutenant of Ireland. ${ }^{62}$ The charges relating to his Irish appointment were meant to establish a consistent pattern of abuse of the rights and liberties of the Irish subject. By extension it could then be assumed that Strafford posed a serious threat to English liberty because of his proximity to the Throne. These charges were meant to prove a general charge of treason.

${ }^{62}$ For a full discussion of the charges relating to Strafford's impeachment see Gardiner, op. cit., p. 218-240; and C.V. Wedgewood, Strafford, London, (1938), p. $\overline{264} \mathrm{ff}$. 
However, in truth, the opposition's case rested on a single, more specific accusation. Strafford was accused of abusing his position of trust by advising Charles to use illegal methods to bring Parliament into line. According to notes taken at a critical meeting between Charles and Strafford, ${ }^{63}$ the Earl had suggested to Charles that Parliament's refusal to grant the revenues for the Second Bishops War gave the King the right to circumvent the constitutional limitations imposed by law. Specifically, Strafford was accused of recommending that Charles make use of the standing army in Ireland. The charge was critical. Had it been proved, it would have indicated that Strafford had advocated the use of the Irish army against the King's own subjects. However, the notes themselves were sufficiently ambigious to allow different interpretation, and had been supplied to the House, by Henry Vane Jr., under very dubious circumstances. Strafford maintained to the end that he had recommended that Charles use the Irish Army in Scotland, in the Bishops War, and not, as Vane and Pym charged, in. England against his own subjects.

Even if the charge had been substantiated beyond any doubt, it still would not have amounted to a clear definition of treason, and that was where the challenge of Strafford's trial began. The whole exercise, in fact, rested on how the opposition and the defense defined the word itself. It was here that the opposition, out of necessity, parted company with established legal precedent:

${ }^{63}$ The notes were originally taken by Henry Vane senior, then Secretary of State, at a Council meeting the previous May, (Perez Zagorin, The Court and the Country, New York, (1971), p. 209

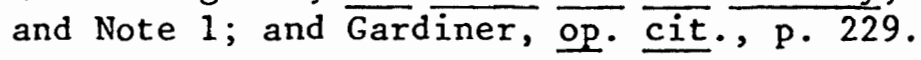


With praiseworthy effort they excavated the mines of legal precedent to the depths to prepare their case. Yet that case rested on a principle really revolutionary in its nature... Treason had hitherto been acts against the King's person and authority, as defined by statute and judicial interpretation. Now it was acts against the Commonwealth rather than the King, as defined by the House of Commons. The supreme crime was one that struck at the King's person or power, but one that undermined the immemorial constifution of the Kingdom by attacking its free institutions.

In specific terms, Strafford's opponents claimed that he had attempted to create a division between the King and his subjects. They maintained moreover, that he had attempted to permanently alter the frame of the constitution. The idea was expressed most clearly by John Pym:

It doth exceed all other treasons in this, that in the design and endeavor of the author; it was to be a constant and permanent treason;...this treason, if it had taken effect, was to be a standing perpetual treason, which would have been in continual act, not determined within one time or age, but transmitted to posterity, even from one generation to another. 65

The extension of Pym's argument was logical, if somewhat overdrawn:

The suggestion here is that strafford is proposing to alter the constitution to one in which the King's authority rests on will, and is unfettered by restraints. This authority, an authority of force, will be odious to the people, who will be likely to rise against it. Therefore, it was argued, to introduce and arbitrary government was to risk civil war, and so to compass the King's death.

The importance of Pym's charges against Strafford rests not only with the novelty of his legal thinking, but in his attempt to encompass, within the charges, the entire premise of ministerial responsibility.

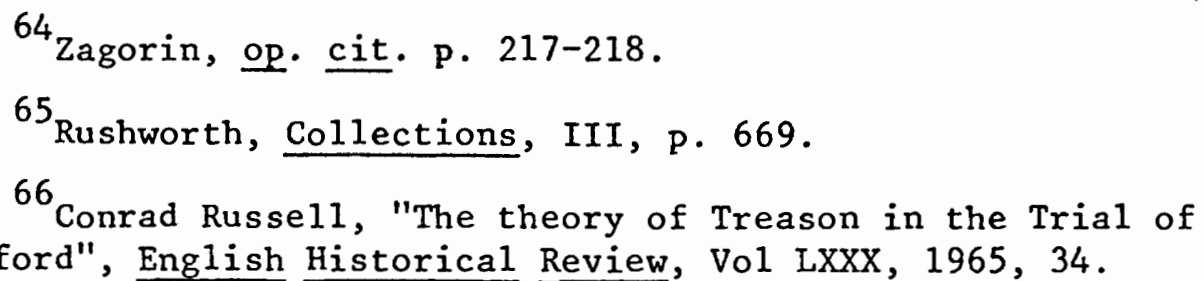
Strafford", English Historical Review, Vol LXXX, 1965, 34. 
Pym's theory was essentially an indictment of all evil councillors, and a sincere and powerful argument in favor of Parliament's right to exercise judgement on the King's ministers. Nonetheless, Pym's definition was not immediately effective in the House of Lords, and as Strafford's trial progressed, it became increasingly apparent that the Commons' case was loosing ground. The Lords had not been convinced that treason had been committed. As they retrenched, the Commons advanced, "the cry for blood... waxing louder."67

By April 1st the unfavorable course of Strafford's trial had created a sense of imminent danger among members of the opposition. That' fear was only compounded by the circulation of a rumor suggesting that the King had plans to use the English Army in London to impose his will on the House. The actual details of the Army Plot, as it was to be called, were revealed to Pym on the 1st. 68 He did not, in turn, reveal them to the House at this point, but it is clear that the rumor of a plot, and the course of Strafford's trial, may have compelled the House to revive the Remonstrance. On 2 April the House issued new instructions to the Committee:

...the Committee of Twenty Four, that was formerly appointed for the Remonstrance of the State of the Kingdom, shall collect the Heads of such great grievances of the Kingdom as they shall think fit; and dispose them into form of a Petition, and present them to the House, so to desire the Lords to join with thisghouse in representing them to His Majesty for redress.

${ }^{67}$ Gardiner, op. cit., p. 307.

${ }^{68}$ The full details of the Army Plot are discussed in Gardiner, op. cit., p. 313-318.

${ }^{69}$ Commons Journals, 11,51 . 
Although there is no written evidence that there was a direct connection between Strafford's trial, the rumor of an Army Plot, and the revival of interest in the Remonstrance, the chronological proximity of these developments, and the fact that Pym maintained a dual responsibility on both the Select Committee for Strafford, and the Committee of Twenty Four make this a logical assumption. Given Pym's growing authority in the Commons, and his understanding of recent events, it is not unreasonable to assume that he brought his influence to bear in committing the House to renew its interest in the Remonstrance. That view is supported by a similar series of events which developed in late Apri1. On the 20th, Edward Hyde reported to the House of Lords that:

The House hath received information, which hath moved some fear in them, that the Ear1 of Strafford may have a design to make an escape, that he hath ships 7 t sea at command, and that the guard about him is weak.

On the following day, the 29th, the Committee of Twenty Four was ordered to meet and prepare the Remonstrance for presentation on the 30th. There is an unmistakable impression left by these two occurrences that the Grand Remonstrance assumed a position of increasing importance at this stage, directly in proportion to the Strafford's fate specifically, and to the course of the impeachment campaign generally.

The report from the Committee was never made, presumably because it was not ready, and because the House was awaiting the King's final address to the House regarding Strafford the next day, on 1 May. Charles's speech was a defense of Strafford and amounted to a final 
plea to the House to abandon its bill of Attainder, which they had, in fact passed and sent to the Lords ten days earlier. The speech was unsuccessful, but it was sufficiently important to compel Pym to act once again. On 5 May he revealed to the whole House the details of the Army Plot, in order to generate renewed pressure for the presentation of the Remonstrance. Pym's revelations caused an uproar in the House. That afternoon the House ordered that:

Intimation be given to the Committee for the Remonstrance of the Stage of the Kingdom, and the Petition; to bring in said Remonstrance and Petitipn, tomorrow morning, upon the duty they owe to the House.

The Remonstrance was not, in fact, presented on the sixth, despite the urgency implied in the order. Probably, the Committee was still not prepared to make its report. More than likely, the Committee decided to forestall the presentation until the House of Lords acted decisively on the Bill of Attainder. The Lords did pass the bill two days later on 8 May. Strafford's fate now rested with the King. Charles signed the Bill of Attainder on the 10th, and not without considerable reluctance. The King's decision had been extracted under extreme pressure, both from the House of Commons, and from the public who assembled, beginning on 3 May, in large and violent crowds to cry for Strafford's death and justice. Despite Charles' well known wishes to the contrary, the House was determined to be rid of strafford at all cost. The outcome of the struggle left Charles bitter and hostile; "My Lord Strafford's condition is more happy than mine." 72

\section{1} Commons Journals, 11, p. 136.

${ }^{72}$ Gardiner, op. cit., p. 367. 
The bitter struggles of the last six months, and particularly the ordeal of Strafford's trial and Attainder, had left the King weakened and isolated. It is some measure of that fact, that on the day that he granted the Bill of Attainder, Charles signed the Act of dissolution, which guaranteed that Parliament could not be dissolved without its own consent. The bill, in fact, usurped a significant prerogative right from the Crown, but the King was apparently too weak or too distracted by Strafford's impending death to contest it any further. In the same day, then, Charles lost his chief adviser and conceded substantial prerogative powers of the Crown. Thus, for both the Crown and the opposition, the death of Strafford was a major turning point.

In the end, Charles' concessions did little to improve his standing in the House of Commons. From their point of view, Charles had protected and defended Strafford, even in his death, and had consented to the:Attainder only after he had been placed in a near-impossible political dilemma. Charles had failed utterly to recognize the importance which the opposition attached to the charges of treason, nor did he appreciate Parliament's sincere belief in the premise of ministerial responsibility. He had, in fact, shown bitter contempt for what Parliament considered its most serious undertaking to date. Charles' attitude toward the House and its proceedings against Strafford served only to widen the gulf between Crown and Commons, when in fact, it should have provided, as it was meant to, a vital bridge between the two. 
The entire episode resulted in an irretrievable loss of trust on both sides. Parliament had counted on Strafford's death as the means to rewrite its relationship with the King, as the means to achieve a direct understanding with Charles, and as the means with which to remove, once and for all, the obstacles to a healthy and productive relationship with the Crown. Instead the force which Parliament employed to achieve its ends merely produced the opposite effect, by perpetuating a profound mutual distrust that made reconciliation impossible, or, at the very least, improbable. 


\section{A NEW RELATIONSHIP BETWEEN CROWN AND COMMONS}

The irreparable damage done to the relationship between Charles and his Parliament began to take effect in the four months separating Strafford's death and the September recess. The mutual distrust which had developed between the two became self perpetuating. The impeachment campaign had failed to produce any significant change in Royal policy, and, in fact, had only succeeded in reinforcing Charles' antagonism toward the House. In response, the Commons began, with increasing frequency, to take matters of policy into their own hands, first with Pym's Ten Propositions, then with a series of legislative bills abolishing Tonnage and Poundage and the Courts of Star Chamber and High Commission. For his part, Charles simply withdrew further into the political isolation which he had created for himself in anticipation of his journey north to Scotland. By August, Charles had managed to abrogate the greater part of his authority and effectiveness as a monarch, and had left the House with the responsibility of establishing national policy. Unfortunately, the Commons' first attempt to exercise that authority, before the recess, resulted in the collapse of Parliamentary unity, and in the creation of political divisions within the House that would ultimately prove fatal.

As a result of these developments, the Grand Remonstrance became increasingly important. The failure of the reform movement 
made progress on the Remonstrance all the more imperative. The opposition, in fact, took possesion of the Remonstrance during this stage and controlled its development from this point forward.

During the next four months the Grand Remonstrance would be significantly altered to reflect not only the collapse of the relationship between Charles and Parliament, but the new responsibilities of the House, and the new political alignments which developed as a result. In the aftermath of Strafford's trial both the King and Parliament began pursuing activities which exacerbated the conflict. The House continued, through its secret committee, to explore the implications of the so-called Army Plot, hoping to find evidence that Charles had intended to use the Army to subdue the House. 73 Charles, having tried and failed to pacify the House with a succession of worthless political appointments to Crown offices, and having lost all semblance of authority and control, let it be known that he intended to visit Scotland, an announcement which, given the presence of the English Army in the North, could only provoke panic in the House.

The resulting relationship between the King and Parliament is evident from the House's unilateral support of Pym's Ten Propositions on 24 June, and by Charles'. reaction to them. The Ten Propositions

${ }^{73}$ Gardiner, op. cit. p. 358. The secret committee consisted of Pym, Holles, Fiennes, Hampden, Culpepper, Clotworthy, and Strode, all lieutenants in Pym's opposition party. Four of the members sat on the Committee of Twenty Four, (Pym, Hampden, Clotworthy, and Culpepper,) and four had sat on the Select Committee for Strafford, (Pym, Hampden, Clotworthy, and Strode.) 
originated in the Committee of Twenty Four, 74 and were reported to the House of Lords prior to their presentation to the King. They consisted of specific and immediate demands as well as far reaching proposals. The immediate demands dealt principally with security. The Propositions requested, not only that the English Army be disbanded, but that Charles' proposed journey to Scotland be delayed until both armies had been dispersed. The other, relatively unimportant requests sought removal of all catholics, including the Papal Nuncio, Rosetti, from their positions of influence at Court, the placement of military forces in secure and trusted hands, and the grant of a general pardon. The most important of all the clauses of the Ten Propositions was, however, that listed as the "Third Head", which concerned "His Majesty's Council and Ministers of state." 75

Both Houses to make suit to his Majesty, to remove from him all such counsels...such as have been active for the time past, and in furthering those courses, contrary to religion, Liberty, Gaod Government of the Kingdom; as have lately interested themselves...to stire division between him and his people... As we desire the removal of those that are evil; so--to take into his council, and for managing the great affairs of the Kingdom, such officers and councillors as $6^{\text {his }}$ people in Parliament may have cause to confide in.

${ }^{74}$ Commons Journals, 11 p. 184. Zagorin (op. cit. p. 247n) is mistaken in assuming that Pym was reporting the Ten Propositions from the Secret Committee for the Army Plot. A secret committee would not be mentioned anywhere in the Journals. The references in the Journals refer to the Committee to prepare Heads, an identical reference used in the order to the Committee of Twenty Four on April 2nd. (see p. 44). The marginal notation indicates that this is a report on the State of the Kingdom, which would only come from the Committee of Twenty Four.

${ }^{75}$ Commons Journals, 11, p. 185.

${ }^{76}$ Commons Journa1s, 11, p. 185. 
This proposal came into being after Strafford's demise, and emerged from a committee responsible for drafting a petition on the state of the Kingdom. The clause relating to the ministers of state is a measure of both Parliament's prevailing mood of distrust, and of the paramount importance which it still placed on the role of the King's councillors. The origin of the document is important because it indicates the growing stature of the Committee of Twenty Four as the focal point of official opposition to the Crown. It also clearly foreshadows the ultimate focus of the Grand Remonstrance as it emerged five months later. For that reason it is important to remember that the Ten Propositions passed the House without so much as a single dissenting vote, and, on their presentation to the Lords, received their immediate endorsement.

Charles responded to the Propositions, in part, the following day. He agreed to disband the army and to dismiss Rosetti. The dissolution of the Army was made conditional on the passage of a bill authorizing a poll tax. The revenue from the poll tax would provide the funds needed to pay back wages to the soldiers. It was not until 13th of July, that Charles responded to the clause dealing with evil councillors, and then only after a renewed plea from the Commons. His answer was characteristically careless and impolitic:

My answer is, that $I$ know of none: the which methinks should both satisfy, and be believed, I having granted all hitherto demanded by Parliament. Nor do I expect that any should be so inadvised, as by slander, or any other ways, to deter any that I trust in my public Affairs, from giving me free Counsel; especially since Freedom of Speech is always granted, and never refused, to Parliaments.

\section{7}

Commons Journals, 11208. 
The reaction to Charles' answer was, not unexpectedly, hostile and swift. On the 23rd of July the Committee of Twenty Four was given a new and expanded assignment:

Ordered. That it be referred to the Committee for the Remonstrance and Petition, to draw up a Remonstrance of the State of the Kingdom and of the Church; in what state this Parliament found it, and what their 980 oceedings have been in reference to the Church and State.

This order represents a major point of transition in the development of the Grand Remonstrance. In the first place, there is a tacit recognition of the responsibility given to the Committee in early February to report on the state of the Church, something not previously mentioned in their commissions up to this point. The major alteration or addition to the Committee's assignment emerges however, from the phrase, "... in what state this Parliament found it, and what their proceedings have been..." This is the first time that the House directed the Committee to frame the Remonstrance in an historical context. The obvious implication is that the House desired some sort of official justification for any demands it might make in the finished document. The question is why, and to whom did the House have to justify its proposals? Having just concluded a highly unproductive exchange with the King using just such an historical argument, it seems odd that the House would proceed to frame the Remonstrance in a similarly provocative fashion. The timing of this particular change is also rather odd. By $23 \mathrm{July}$, Parliament had extracted a number of major concessions from the king. They had received his assent to the Triennial Act and the Act of Dissolution,

${ }^{78}$ Ibid, 221, Rushworth, op. cit., p. 355. 
both of which guaranteed Parliament's security, the Act abolishing Tonnage and Poundage, and Acts abolishing the Courts of Star Chamber and High Commission. In addition, both Laud and Strafford had been disposed of. Surely such a rehearsal of events could only compromise the ultimate effect of the Remonstrance on the King. Therefore, even in July, the Committee apparently intended the Remonstrance to have a far wider audience that its simple format might have indicated. This represents a critical shift in the opposition's political strategy. The relationship between the King and Parliament had apparently deteriorated to such an extent that the Committee, and, in fact, the House itself, was anticipating the need to enlist popular support for its position. The House and particularly the opposition, could not have forgotten the effect which the London mob had on Charles' decision to assent the Strafford's Attainder, just two months earlier. Clearly, the Remonstrance was being designed for general circulation. This change in the general thrust of the Remonstrance was, if not exactly revolutionary, certainly reflective of a more radical approach. Pym and his associates had gained considerable strength in the House and had begun to react to the deteriorating relationship with the King in a singularly aggressive fashion. The opposition leaders had apparently abandoned all hope of a reconciliation, and had determined, instead, to stake their hopes on the cumulative effects of the Remonstrance.

That impression is reinforced by two very important events which occurred on the 2 and 3 August. On the 2nd, the House ordered "The Committee for the Remonstrance of the State of the Kingdom 
and the Church, to bring in those Remonstrances." 79 This entry from the Commons Journals indicates an important change. What had been one Remonstrance now consisted of two separate petitions, one for the Church, the other for the State. On the $3 \mathrm{rd}$, the original Committee of Twenty Four was replaced by a much smaller committee. The new committee consisted of Pym and his immediate lieutenants, all members of the dedicated and committed opposition - Culpepper, Vane, Hampden, Fiennes, Strode, Earle, and St. John. The new committee was instructed "to bring in the Remonstrances on the State of the Kingdom and of the Church, by Friday next; premptorily; and will have the power to sit when they please; and adjourn at their own discretion." 80

There are a number of very important details about these two events. The order to divide the Remonstrance into two separate petitions was, quite obviously, the result of the opposition's understanding of the volatile and divisive nature of the religious question, and of their desire to separate secular and religious issues, in order not to loose the whole Remonstrance for lack of unified support for its religious provisions. The lessons learned from the debate on the Root and Branch Bill, when the opposition divided against itself, and those learned from the-unanimous support offered the Ten Propositions, were obviously at work. The demise of the original Committee of Twenty Four is a more striking occurrence. It testifies

${ }^{79}$ Commons Journals, 11, p. 234. St. John was 1isted simply as Mr. Solicitor. He had been appointed to the position in January 1641. The position was of no political importance.

80 Ibid, 234 . 
to the enormous power which Pym and his lieutenants had come to exercise in the House. Of the original members of the Committee, only Pym, Hampden, Earle, and St. John remained. Two members, Digby and Seymour, had moved to the Lords, and one, Heyman, had died. Gone were all of those members who had opposed Pym's group over religious issues, Rudyerd, Strangeways, and Selden. Replacing them were the likes of Vane, Strode, and Fiennes, all three members of the most radical contingent in the Opposition force.

The wording of the Commons order on the third is also important. The new committee was to bring in its Remonstrances "premptorily" on Wednesday the 12 th of August. The order was meant to convey a sense of real urgency. The Committee obviously felt that it was imperative, given the King's pending journey to Scotland, that the House had the Remonstrances in hand. Possibly this is why the Committee asked the House to overlook standard procedure, and allow it. to "sit when they please, and adjourn at their own discretion."

On Saturday the 7 th the Committee was ordered to meet on Monday the 9th. The King planned to leave the next morning for Scotland and the matter had become even more pressing. Oddly, the order on the 7th included a notation that "My Lord Falkland be added to the Committee." 81 Falkland was, and had consistently been, opposed to the greater part of Pym's political strategy on both secular and religious issues. While Falkland did vote for the Attainder of Strafford, he was, certainly on religious grounds the odd man out on this new committee. Perhaps the Committee recognized the need to ${ }^{81}$ Commons Journals, 11, p. 244. 
have, at least on paper, some semblance of support from a more conservative faction of the House, if only to dispel the impression that they themselves represented a small and reactionary part of the Commons.

By 12 August the Committee had progressed to the point of assigning responsibility among its members, for the presentation, and presumably the authorship of the two Remonstrances:

Ordered. That Mr. Pym, Mr. Hampden, Mr. Strode, and Sir Culpepper bring in the Remonstrance of the state of the Kingdom on Saturday morning next; and $\mathrm{Mr}$. Finnes, Sir H. Vane, The Remonstrapce of the State of the Church, at the same time.

The assignment of authorship responsibilities was a natural one which would have appealed to the prevailing interests of those involved. 83 Pym's strongpoint was never religion. His interest focused on secular and constitutional issues. Fiennes, on the other hand, had a singular understanding of religious problems, an understanding he had brought into play in the debate on the Root and Branch Bill in early February. Interestingly, Rushworth's entry for this day records a debate "of many passages of the Remonstrance of the State of the Kingdom, and of the general grievances of the people." 84 A debate probably did

82 Ibid, p. 253. It is surprising that neither St. John or Strode are mentioned in this order as they surely must have taken part. It is less surprising, I think, that Falkland's name is not mentioned.

${ }^{83}$ Henry L. Schoolcraft, "The Genesis of the Grand Remonstrance" University of IIlinois Studies, Vol. I, 1902.

${ }^{84}$ Rushworth, of. cit. p. 375. Rushworth claims that from the 18th to the 26th of August, the House debated the Remonstrances. It seems unlikely since there is not a single corroborating reference in any of the other sources, and since Rushworth was, in fact, not in attendance at the time. (Schoolcraft, op. cit. p. 168.) 
take place on this day because the Committee was due to report to the House on the $12 \mathrm{th}$. In all likelihood, the debate produced the order to divide the committee into subcommittees on Church and State. On the 14th the Committee was ordered to meet and bring in the Remonstrances, "with all convenience speed." 85

This flurry of activity during the first two weeks of August was undoubtedly the result of the opposition's concern over Charles' trip to Scotland. The treaty with the Scots was not completed and ratified by the House until the $10 \mathrm{th},{ }^{86}$ the very day that Charles left for Edinburgh. The proceedings of the 12 th and 14 th reflect the level of paranoia felt by the House as a result of Charles's departure on the 10th. The king had made no secret of his wish to "refresh himself from the vexation which both Houses, or one of them... daily gave him." 87 In fact, he had been adamant about going and had refused to accept any further pleas for delay. He had, after all, delayed the trip some two months already. Unfortunately, Charles had, if only by implication, made equally clear that his journey was intended to solidify his support in Scotland, and hence his power and prestige at home. The feeling of insecurity running rampant through the House was not helped by the fact that "At that very moment,

\section{5}

Commons Journals, 11, 257. The notation from the Diurnal Occurrances reads, "After this it was ordered by the House that the Remonstrance of the general Grievances of the Kingdom should be brought into the House." Diurnal Occurrances, $23 \mathrm{July}$ - 16 November, Microfilm, Yale Center for Pariamentary History, p. 44.

${ }^{86}$ The treaty provoked the first meeting of the House of Commons on a Sunday (the $8 \mathrm{th}$ ) in the history of Parliament.

${ }^{87}$ Clarendon, 오. cit. p. 368. 
the Scottish Commissioners were boasting that their nation would 'do all in its power to place the king in his authority again. "'88 For all of Charles' professed desire to attend to the needs of his Scottish subjects, the prevailing impression of the House, and particularly the Opposition, was that the King was abandoning his responsibilities in England, in order to regroup in Scotland, and in order to assemble enough political and military power to return and overwhelm the opposition in the House. The House saw itself pitted against a unified and ultimately hostile block of power gathered behind the King in Scotland. Parliament's understanding of the political situation in Scotland was naive at best. Nonetheless, the fear itself was very real, and Pym and his associates obviously saw the necessity of bringing the Remonstrance to fruition, if only as a tool to enlist public support for past and future reforms. Even so, its presentation was again delayed in favor of more pressing business.

The distrust which now clearly defined Parliament's relationship with the King was translated into statute on 20 August, when the House passed an Ordinance establishing a party of Parliamentary commissioners to attend the King in Scotland. The idea of a Parliamentary commission had first been proposed by Pym, and adopted by the House on 10 August, just before the King left. The resolution adopted on that day appealed to the Lords to join the House in petitioning the King to appoint a commission of members "as shall be nominated by Both Houses, or either of them, authorizing them to ${ }^{88}$ Gardiner, op. cit. ix, 417. 
see, and take care that the Acts that concern this Kingdom are perfected in the Parliament of Scotland." 89 For all of this deferential language, the implications of the request are clear. In the first place, the commission was to be nominated by Parliament and not by the King. Secondly, while the group's mission was, ostensibly, to secure the passage of the Act of Pacification in the Scottish Parliament, in truth, the commissioners were meant to monitor Charles's every move, and report it directly to the House. Charles was astute enough to recognize their true intentions, and politely ignored the whole thing. The Lords, in fact, only answered the Commons' appeal on the 16th, and then qualified their support by requesting that the Commissioners not be sent until a messenger could be dispatched to Charles to obtain his official warrant. 90 That having failed as well, the House resorted to a formal petition containing both the original commission and an accompanying set of instructions to the commissioners, which they then passed on the 19th. 91 The petition still required the King's assent, and that was simply not forthcoming. On the 20th, therefore:

The Committee appointed to examine Mr. Walsh, and $\mathrm{Mr}$. Selden, and the Lord Falkland, do forthwith retire...to prepare some

${ }^{89}$ Commons Journals, 11 , p. 249.. The motion is mentioned in the Diurnal Occurrances with an interesting variation in the wording; "After this it was moved that there might be a Comittee of Both Houses appointed to go to Parliament in Scotland to see there be a fair correspondence kept between both Parliaments." Diurnal Occurrances, op. cit. p. 93.

$$
{ }^{90} \text { Commons Journa1, } 11,259 .
$$


Authority and Warrant, to be derived to thgse gentlemen of this House, that are to go to Scotland.

The result of their efforts to prepare "some Authority and Warrant" was the Ordinance passed by the House on the 20th. The ordinance represented a major advance in Parliament's usurpation of prerogative right. Up to this point, the Triennial Act and the Act of Dissolution had appropriated significant powers of the Crown. But they were essentially preventative acts which protected Parliament's right to assemble. The very form of bill which the House used in this case, the Ordinance itself, called into question the fundamental legal premise that Charles' assent was required to pass any bill into law. The passage of the Ordinance, therefore, put the king on notice that the House considered itself able to establish policy independently, in total disregard of his authority. Furthermore, the quasi-legal foundation which the House used to justify its action was, at best, extremely weak, and rested, for the most part, on $D^{\prime}$ Ewes' antiquarian citations of Medieval law, the better part of which were inaccurate and inappropriate. 93 Nevertheless, the House was apparently convinced and the passage of the Ordinance established a precedent which the House was to use frequently in the coming months:

From Henceforth the term 'ordinance' would be taken to signify, not, as it had done in the Middle Ages, a declaration made by the King without the necessary concurrence of Parliament, but a declaration of the

${ }^{92}$ Ibid., 263. It would be interesting to know why selden Falkland, and Walsh were being examined.

${ }^{93}$ Gardiner, 오. cit., p. 4. X. 
two Hguses without the necessary concurrence of the King.

The Ordinance and Instructions to the Scottish Commission demonstrate, in large measure, the atmosphere of pervasive distrust in the House, and moreover, indicate that the House had decided to assume the initiative and to commence directing matters of state on its own. This was not particularly surprising given the fact that Charles had left the country thereby depriving it of even a semblance of Royal authority or leadership. The method and manner with which the House attempted to fill the void are interesting. Between the 20 th of August and the 9th of September, the House attempted to accomplish two things; to establish an administrative committee to govern the nation during the upcoming, and already agreed upon recess, and to settle decisively the still uncertain religious state of the Kingdom.

The religious crisis which Parliament faced in the first week of September was, in a sense, one of its own creation. For whatever the Laudian innovations may have meant to the Puritan theorist, Laud did, in fact, create a convincing uniformity in religious worship. Parliament had succeeded in removing Laud from his position of influence, and had successfully discredited any legacy he may have left the Church, but they had not, by September 1641 , been able to agree on either an alternate form of Church government, or an acceptable doctrine of worship that would have guaranteed an equally effective unity within the English Church:

$$
{ }^{94} \text { Ibid., p. } 4 .
$$


Under the most favorable circumstances the difficulty of moulding the ecclesiastical institutions so as to meet the wants of the time, would have required the most consumate prudence. The traditional belief of centuries, held alike by the zealot and the politician, was that religious liberty was but another name for anarchy, and that it was the duty of the state to see that no man was allowed to worship as seemed right in his own eyes.

Parliament asked for, and got, the responsibility to establish uniformity in religious worship. It was a challenge which Parliament was not able to meet. From the outset of debate on 1 September, it was clear that the division, similar to that precipitated by the Root and Branch Bill, would again come into play:

The House of Commons had great debate this date about the Common Prayer, to have some alteration made therein; which being suddenly started, gave occasion to a very Hot debate.

Even Pym's stalwart champion Culpepper deserted camp to support preservation of the Book of Common Prayer. In the end, the issue of the Prayer Book was side-tracked in favor of a general condemnation of the Laudian innovations. The House was able to agree on an order requiring the removal of all communion tables from the east end of the Church, and removal of all "Crucifixes, Scandalous Pictures of any one or more persons of the Trinity." 97 The order also forbade the exercise of corporal bowing at the name of Jesus. While the House of Lords deliberated their own proposal, the House took their initiative a step further, and allowed that "preaching of God's word

$$
\begin{aligned}
& { }^{95} \text { Gardiner, op. cit. } x, 12 . \\
& 96 \text { Rushworth, op. cit., p. } 386 . \\
& 97 \text { Commons Journa1s, } 11, \text { p. } 279 .
\end{aligned}
$$


be allowed in the Afternoon." 98 This additional clause in the Commons' order gave tacit approval to the concept of "lecturing" in the English Church, a strictly puritan innovation that was unlikely to enlist wholehearted support. 99

The Lords simply could not subscribe to the House's order and promptly tabled the whole resolution. They then proceeded to issue an order of their own, requiring that "the Divine Service be performed as it is appointed by the Acts of Parliament... and that as such as shall disturb that wholesome order, shall be severely punished according to the law."100 'The Lord's order was, if anything, a direct challenge to the Commons' order, and was met by a proposal, initiated, by Pym, oddly, that the House appeal to the King to revoke the Lord's order. ${ }^{101}$ In the end, the House agreed to publish its own resolution, with that of the Lords, attaching a surprisingly concilatory message which expressed their hope that:

when both Houses shall meet again, that the Good propositions and Preparations of the House of Commons, for preventing the like Grievances, and reforming the Disorders and abuses in Matters of Religion, may be brought to perfection.

The attempt to resolve the religious question had, for all intents, ended in failure, or at the very least, in a stalemate. In

\section{8} Ibid, p. 279.

${ }^{99}$ For a full discussion of the importance of this development see Paul S. Seaver, The Puritan Lecturships, Stanford, (1970).

${ }^{100}$ Rushworth, op. cit. 387 .

${ }^{101}$ Gardiner, op. cit., $\mathrm{x}, 17$.

${ }^{102}$ Rushworth, op. cit. p. 387. 
the absence of any Royal authority or direction, the two Houses found themselves pursuing altogether different paths to the same end. Even the apparent success of the puritan constituency in outlawing the Laudian innovations is mitigated by the fact that the House was substantially reduced in membership. On the 1st, when the initial vote on the innovations took place, "there was then in the House 115 members, most of the House being gone to the country, by reason they intended to make a recess."103

Rushworth's note on the attendance in the House when this important issue came to a vote, clearly foreshadows the problem which the Opposition would face after the recess. The order on innovations and lecturing in the Church had been passed by minority of the House's membership. The religious controversy remained, therefore, largely unresolved.

Parliament's efforts to establish some sense of governmental authority during the recess met with more success. Both Houses were able to appoint standing committees to meet during the period. The recess was to last from the 9 September until 20 October. The House committee consisted of 47 members, chaired, not surprisingly, by John Pym. It was empowered to meet every Tuesday and Saturday, or at such times as they found necessary. The committee was directed to carry on any discourse with the House commission in Scotland to ensure that matters prevailed according to their instructions, and to make certain that "all orders of the House be punctually observed."104 103 Ibid, p. 385. ${ }^{104}$ Rushworth, 오. cit. 387 . 
The committee itself was something of a novelty. Never before had it been necessary to appoint a parliamentaxy committee to convene during a recess, or to confer upon it such an all encompassing authority. Such was the vacuum that Charles had created that the House felt it necessary, both for its own preservation, and for that of the Kingdom, to take command.

Since the recess is such a natural breaking point in the affairs of the Long Parliament, it provides a useful vantage point from which to survey the conditions created by the House in September 1641. The most obvious condition was the prevailing sense of disorder and discontinuity in the body politic, which was, for the most part, precipitated by the deteriorating relationship with the Crown. The efforts of the House to deal effectively with reform had suddenlỳ been suspended by an urgent need to establish a basic stability within the realm. There is a hint, in the religious debates of early September, of Parliament attempting to go a step further, and establish national policy. But the attempt had been futile and would be ultimately divisive. Nonetheless, the attempt itself was prophetic:

Ten months of unresolved conflict had brought the monarchical constitution to the verge of disintegration, and the opposition party was already forging the elements of a parliamentary governing ${ }_{1}$ g $S$ wer to replace the decaying supremacy of the Crown.

${ }^{105}$ Perez Zagorin, op. cit. p. 250. 


\section{CHAPTER V}

THE COLLAPSE OF CONSENSUS IN THE HOUSE

In the final months of 1641 , the Opposition attempted, as it had before the recess, to dictate policy to both the king and the House at large. Its attempts were met with increasing resistance as debates on the Irish Rebellion and the continuing religious controversy highlighted the growing radicalism of the Opposition's program. As debate increased and became more heated, the division in the House became more pronounced. The unity which had characterized the House's previous efforts of reform dissolved, and a distinct party began to emerge in support of the King. The opposition attempted to meet this challenge by forcing the House as a whole to declare its position on the comprehensive platform of reform contained in the Grand Remonstrance. By forcing the Remonstrance to a vote, the opposition merely guaranteed that the House would divide in a way that made reconciliation impossible and Civil War inevitable.

The opposition's control of the affairs during the recess was vital to its strategy in the ensuing months. The activities of the standing committee of the House during the recess are probably most clearly outlined in Pym's speech to the Commons on 20 October. 106

${ }^{106} \mathrm{D}$ 'Ewes account of the committee's business is the only available source, (Coates/D'Ewes, p. 2-15). It begins on 12 October and covers only the two subsequent meetings on the 16 th and 19 th. The entries show the committee dealing with those specific problems arising out of the Order on Innovations, the disbanding of the Army, and correspondence with the House commission in Scotland, all of which are covered in Pym's opening speech. 
Pym's speech was a carefully worded and carefully contrived attempt to use the events of the interim period to his advantage. He spent a notably brief amount of time discussing the committee's actions with regard to four major items; the Order on Innovations of September 9th, the disbanding of the army, the enforcement of the Poll Tax, and the petitions from Ireland. He then launched into an extended discussion of the correspondence from Scotland surrounding the crisis known as the "Incident." The Incident was, in short, a conspiracy to arrest the two most powerful members of the Scottish Parliament, the Earl of Argyle and the Marquis of Hamilton, on grounds of treason. The plot itself originated, as far as Charles was concerned, in a letter from the Earl of Montrose to the King on October 11, in which he suggested that he could prove a Hamilton a traitor. Whether or not Charles was willing to pursue the arrest was not ultimately important. The leaders of the plot had already put their plan to work by the time the King received Montrose's letter. Led by the Earl of Crawford, the conspirators proposed to abduct the two leaders and, if necessary, dispose of them altogether. In the end, the plot was betrayed, and Hamilton and Argyle fled the city.

Charles' involvement in the whole affair was, at best, ambigious, but the circumstantial evidence left a distinct impression that he had had a hand in it. Given the difficulties which both Hamilton and Argyle had inflicted on Charles in the Scottish Parliament over the appointment of Royal officers, it is not surprising 
that Charles was suspect. 107 It is even less surprising that Pym would seize the incident as a tool to incite the English House to further opposition. When he presented the letters of the Scottish Committee to the Committee for the recess, before Parliament convened, Pym had indicated that the parallel situation might exist in England:

Mr. Pym further showed us that he had been advertised at several times for the space of about ten days last passed that there was some great and dangerous design plotting again here at home, wherein he did now believe that there wâ a correspondence with the conspirators in Scotland.

When Parliament assembled the following day on the 20th, Pym had no need to stress the connection. The debate provoked a not unexpected dispute between the emerging parties in the House. There is an unmistakable impression that Pym's tactics had been too patently obvious and, furthermore, that the recess had given members time to reconsider the events of the last months with some perspective. In quick succession, D'Ewes, Hyde, Falkland, and, interestingly, Strode dismissed the parallel conspiracy idea. 109 D'Ewes, "and divers others" had failed to perceive "any clouds and mists of some dark and evil spirits which were not yet dispersed."110 Even so

${ }^{107}$ Gardiner gives a full and accurate account of the incident, (History, X 22-26). Charles had been forced by the Scottish Parliament to grant them the right of prior approval of his appointments to to government offices, a concession not lost on the political strategists in the English Parliamentary opposition.

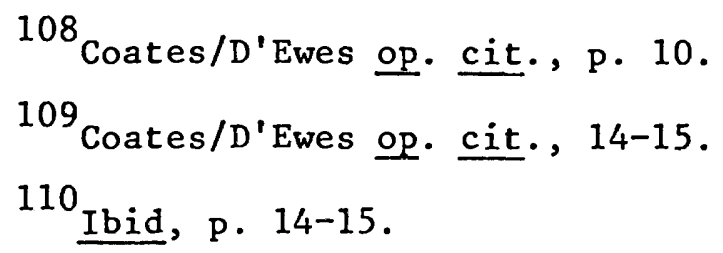


Pym had been able to secure a conference with the Lord which ultimately established military protection for the House. 111

D'Ewes had suggested, during the course of the debate, that the House move to a discussion of its most urgent assignment, "the settling of the matter of religion which will bee as a salve to cure al1 our soares."112 It is clear that D'Ewes recognized the urgent need to resolve the ecclesiastical dispute in order to establish some sense of national order and stability. It is equally clear that Pym saw, in the same issue, a battleground that could only undermine the solid block of support from which he directed the opposition. However, the religious controversy was not to be dismissed. The House's Orders on Innovations, passed on 9 September, had not, it must be remembered, the universal support of the House, or even a major portion of it. ${ }^{113}$. The recess committee's order on the 28 th of September to publish its instructions, for distribution, had not endeared either the committee, or the Orders themselves, to the remaining members of the House of Commons. Accordingly, on 21 October, the day after Parliament convened, the Orders were immediately challenged. "Sir Edward Dering and Mr. Bridgeman...moved against the validitie of our said Orders, and that none were bound to observe them and none could be punished for the neglect of them."114

111 Commons Journa1s, 11 , p. 290. 112 Coates/D'Ewes, op. cit. p. 15.

113 I have not been able to establish the figures for the division on the Orders. Even so it is clear from Rushworth (IV, 387) that the House was significantly reduced.

${ }^{114}$ Coates/D'Ewes, op. cit. p. 19. 
The direct challenge contained in Dering's speech was a clear reflection of his attitude toward Pym's group and their tactics. The speech itself is suffused with the most bitter contempt:

It is very true... that your late order and Declaration are much debated and disputed abroad; perhaps it may be a good occassion for us to redispute them here...Your Orders, (I. am out of Doubt) are powerful, if they be grounded on the laws of the land... But Sir, this Order is of another Nature, another Temper

Sir, there want not some abroad Men of Birth, Quality and Fortune, such as know the strength of our jobs here, as well as some of us... They know they sent us hither as their Trustees, to make and unmake laws, they know they did not send us hither to Rule and Govern them, by Arbitrary, Revokable, and. Disputable Orders, especially in religion. No time 1 if fit for that, and this time is as unfit as any.

In the end Dering's speech provoked an extended debate over the validity of the Orders. The outcome was undecided, in spite of what Nicholas reported to the King that the Order was "conceived by most in that House not to be justifyable by law, and therefore, not binding. "116

The importance of Dering's speech really lies in the attitude it conveys, and in the division in the House which he at least, felt existed over the question of religion. The opposition was unable to field an equally imposing speaker, and, instead, managed to delay the debate indefinitely on this and several subsequent occasions. The Orders had been a dreadful miscalculation.

The Opposition moved instead to introduce a new version of the Root and Branch Bill, which had been abandoned in the late summer. The new Bishops Exclusion Bill was presented on 21 October, passed on ${ }^{115}$ Rushworth, ㅇp. cit. p. 392. ${ }^{116}$ Coates/D'Ewes, op. cit., p. $20 \mathrm{n} .9$. 
the $23 \mathrm{rd}$, and sent to the Lords, after only token opposition from Hyde, Falkland, and Dering. 'Pym's tactics had succeeded, once again, in diverting attention from the question of religious worship, to a broader question of ecclesiastical government. This time however, the King responded in kind. On the $25 \mathrm{th}$, Nicholas, the King's correspondent, passed on a letter from Charles to the House of Lords:

I hear that it is reported that at my return that I intend to alter the government of the Church of England... Therefore I command you to assure al1 my servants that I am constant to the discipline and Doctrine of the Church of England established by Queen Elizabeth and my father, and that I resolve $1 \overline{7}$ by the Grace of God--to die in the maintenance of it.

The King had effectively responded to the threat, (in rather prophetic language), and had deprived Pym of his initiative. Not surprisingly, on the same day the House of Commons "Ordered, That the declaration concerning the State of the Kingdom, be presented to the House on Friday next."118 since the Remonstrance had not been heard of since 14 August, it is fair to assume that its revival was the direct result of the political events of the first five days of the session. Pym could not have failed to recognize the antagonism toward his fundamental religious platform in the House, or to appreciate the effect of Charles' timely intervention. A more direct and definitive course of action was needed.

By this stage in the development of the Long Parliament, a major transition had taken place:

Both sides were driven by their antecedents to misunderstand the fundamental conditions of government. Charles believed

117 Gardiner, op. cit. p. 39., \& Note 1 . ${ }^{118}$ Commons Journals, II, p. 294. 
that an existing system could be maintained in the face of widely felt dissatisfaction. Pym believed that a new system could be introduced by a mere parliamentary qajority in the face of dissatisfaction equally widely felt.

It was becoming necessary for members of Parliament to decide which approach to the growing crisis of English Government could best provide a permanent solution.

Some measure of the perceptible shift in allegiances in the House is demonstrated by the debate on the 28 th of October. Robert Goodwin began the debate:

Touching ill counsellors, that if we did not take a course to remove such as now remained, and to prevent others from coming in hereafter, all wee had done in this Parliament would come to nothing and we should never be free from danger.

Goodwin was seconded by Strode "with great violence," and was responded to by Hyde, who condemned the motion, and interestingly, by $D^{\prime}$ Ewes himself, who took great pains to outline what he felt his moral and civil obligations were in defending the Crown's hereditary right of appointment. D'Ewes proposed instead "that wee should leave the disposition of great offices to the King, only to move him by way of petition." 121 Somehow the constitutional arguments of the kind $D^{t}$ Ewes used to support the Ordinance and Instructions, were no longer operative for him. In the end, a majority of the House supported D'Ewes and appointed a committee to petition the King in a separate resolution.

119 Gardiner, X, 40.

${ }^{120}$ Coates/D'Ewes, op. cit., p. 45. ${ }^{121}$ Ibid, p. 47. 
The failure of Goodwin's motion and its substitution with a petition is significant as much for what it did not produce as for what it did. The motion itself was almost identical to the famous Third Head of the Ten Propositions which was presented and passed unanimously on 24 June. The events of the ensuing four months had obviously caused a major realignment of political feeling in the House. Pym's majority was slipping away, and the balance of power in the Commons was beginning to shift toward a more equitable distribution between followers and opponents of the king. The following day, the Committee of Twenty Four was ordered to meet the next day, and bring in the Remonstrances on 1 November. ${ }^{122}$ Certainly, the revival of the Remonstrances on this day reflected the anger of the opposition over the failure of Goodwin's evil councillor motion. Almost as certainly it reflected the intense debate on 29 October surrounding the King's appointment of five new bishops. Charles had made the appointments in full knowledge that the House of Lords was at that very moment contemplating the Bishops Exclusion Bill. He also clearly understood that two of the five bishops he appointed had already been impeached by the House for their part in the authorship of the illegal Canons of 1640.123

The battle lines were clearly drawn and ready for the presentation of the Remonstrances on the 1st, when the news of the outbreak of the Irish rebellion descended on the House. The Irish uprising could not have provoked more fear or shock in the Commons. Again, religion was the primary reason.

\section{2} Commons Journa1s, 11, p. 298.

${ }^{123}$ Gardiner, opp. cit. $x, 40$. 
The armed revolt by Catholics anywhere, in and of itself, guaranteed a violent response in England, and particularly in a Parliament controlled by Puritan sentiments. Al1 of the inherited English hatred of Catholics, and particularly Irish Catholics, rose to the occasion. The exaggerated reports of atrocities are legendary, but the fear in the House of Cormons was monumental, and to be expected, for a number of reasons. In the first place, the rebels made it clear from the outset that their efforts were predicated on a resounding fear of the Long Parliament itself, ${ }^{124}$ and on the potential, if not inevitable repression of Irish Catholics that must come from the permanent ascendancy of a puritan opposition in the English House of Commons. From the start, the rebels had proclaimed their allegiance to the King, and the support of his constitutional rights against the encroachment of the Long Parliament's legislation, ${ }^{125}$ a fact not lost on the members of the House. The Catholics in Ireland were obviously we1l aware of the raging crisis in English government, and were astute enough to recognize the advantage in perpetuating it by siding with the King. (Charles had, in fact, corresponded with the leaders of the Catholic opposition sometime in August, apparently in the hope of enlisting their eventual support in his struggle with the Commons.) $126^{\circ}$

\section{${ }^{124}$ Zagorin, op. cit., p. 259.}

125 Rushworth, op. cit., p. 386. "The Grand Remonstrance of the Catholics of Ireland." Entry in Rushworth dates from March 1642 , but reflects the same political sentiments as the document of the same name issued in late 1641. (Zagorin, op. cit., 258, note 1.)

${ }^{126}$ Gardiner, op. cit., p. $7 \mathrm{X}$ and note 1 . 
Pym's response to the crisis was to appeal again to the House to limit the King's powers of appointment, and to thereby remove any questionable influence emanating from the King's ministers. On 5 November, Pym, reporting from the special committee on Ireland, proposed that the House send, with its new instructions to the Scottish comittee, an admonition to the King that "unless the King would remove his evil counsellors and take such counsellors as might be approved by Parliament, we should account ourselves absolved from this engagement."127 Pym had hoped that the pressure of the Irish crisis would finally compel the House to agree to his motion. Again he had miscalculated. Pym promptly had the tables turned on him by Edmund Waller:

As the Earle of Strafford had advised the King that because we did not relive him (in the Bishops Wars) he was absolved from all rules of government, so by this addition on the contrarie, we should pretend that if the King did not remove his ill counsellors wee were absolved frop 28 ur duties in assisting him in the recovery of Ireland.

Waller's response provoked a violent outburst from Pym who felt he had been misrepresented. He called on the House to censure him, or require Waller to make reparation. In the end, Waller was sent from the House and the debate was adjourned, something of a reflection of Pym's prestige in the House. However, on the following day Pym's motion was again heatedly debated, but the day's business finished with the question still unresolved. ${ }^{129}$

${ }^{127}$ Coates/D'Ewes, op. cit., p. 94. 128 Ibid, p. 95.

${ }^{129}$ Ibid, p. 102, Commons Journals, 11, p. 307. Gardiner is mistaken here in saying that on the 6th Pym's motion was "deliberately rejected." (Gardiner, X, 56) Both the Commons Journals and D'Ewes are very clear on this point. The question was never put to the House. 
Accordingly, on the 8th, Pym came to the House armed with another modified version of the same motion. This time Pym prefaced his demands with a concilliatory recognition of the Common's loyalty and obedience to the King. However, if anything, the essense of this new proposal was even more threatening. After a predictable recitation on the evils of the King's ministers Pym presented the motion:
We shall be forced by the discharge of the Trust we owe to the state, and to those we represent to resolve upon some such way of defending Ireland from the rebels, as shall concur to the securing ourselves from such mischevious Council and Designs as have been and still are in Practice and Agitation against us...

The motion was very carefully worded to make the question of the King's ministers an integral part of the Irish Crisis. The implication was, of course, that the Rebellion itself was a product of misguided Royal policy. The motion was an expression of profound distrust. It was also a not very carefully veiled declaration of Independence:

...Commend those aids and contributions which this great necessity shall require, to the custody and Disposing of such persons $3 g^{f}$ Honor and Fidelity, as we have cause to confide in.

After an extended debate the motion was put to a vote and passed by a division of 151 to $110 .^{132}$ obviously; the event marked a major success for Pym. In the final analysis it amounted to a declaration of constitutional war with the King because it asserted

130 Rushworth, op. cit., p. 424.

${ }^{131}$ Ibid.

${ }^{132}$ Coates/D'Ewes op. cit. p. 105. 
a right for Parliament that could not possibly have been supported by legal precedent or custom. It was precisely the kind of challenge which Charles could be counted on to summarily reject, and which the House of Lords ultimately did. Furthermore, the division itself was indicative of a far more important development in the Commons. While Pym's party carried the motion by forty-one votes, it was a vastly smaller majority than on any previous vote on a major constitutional issue. The House had, for all intents and purposes split decisively. Pym's supreme abilities as a Parliamentary tactician had accomplished their short term end, but at considerable expense.

It was: surely no coincidence that Pym chose 8 November to. introduce the Grand Remonstrance. Given the volatile nature of the motion on evil councillors, Pym must have felt it necessary to have an alternate course of action available. The frequency with which the Remonstrance and the Committee are mentioned and directed in conjunction with, or immediately after, a major political crisis, leaves an unmistakable impression that Pym's small committee viewed the Remonstrance as an alternative weapon in its struggle for supremacy. There is very little question that the Remonstrance had long since lost its initially intended audience and had become an open appeal for public support. Clauses in the document itse1f attest to this change. ${ }^{133}$ Therefore, as the opposition's strength

\section{${ }^{133}$ Clauses 145-6 refer to the King entirely in the third} person, a rather odd form of address for a petition to the King. Likewise, the Remonstrance contains a reference to the recent quarrel with the House of Lords over the Bishops Exclusion Bill, refers to the Lords as a third party, and accuses the Peers of obstructing the House's efforts to reform Church and State. (Clause 170) 
began to wane in the face of its increasingly radical proposals, the Remonstrance became correspondingly more important.

On the $8 \mathrm{th}$, the Remonstrance appeared without the usual prior order of the House. There is nothing in either the Commons Journals or D'Ewes' Journal to indicate that it had been scheduled for that date. In addition, it was presented to the House in a surprisingly disorganized state. In the first place, the two separate ordinances which had been created on, 2 August, suddenly appeared together in a single document, with religious and secular grievances carelessly interspersed. $^{134}$ References appear in the finished document which had obviously been written in August, and had not been deleted by November when subsequent events would certainly have dictated that they be removed. ${ }^{135}$ The impression left by these facts is that the Remonstrance was prepared in inordinate haste to meet the pressing needs of the opposition in early November. The fact that the Remonstrance emerged as a single document is somewhat less easily explained. Probably, the two earlier Remonstrances were joined on purpose. Pym may have felt that affairs in Ireland and Scotland were sufficiently critical to compel the House to support the secular provisions with enough conviction to overlook their objections

$$
{ }^{134} \text { Schoolcraft, ㅇp. cit., p. 39-40. }
$$

${ }^{135}$ For instance, paragraph III refers to the revenues to be obtained from the Poll Tax, and specifies that "if duly levied it may equal L600,000." By October it was quite clear that the Po11 Tax had been a complete failure, and the whole project had been abandoned (Schoolcraft, op. cit., p. 41-42). A complete copy of the Grand Remonstrance is contained in Rushworth, op. cit., p. 438ff., and in S.R. Gardiner, Constitutional Documents of the Puritan Revolution, Oxford, $(1 \overline{889), \text { p. } 202 \mathrm{ff}}$. 
to its religious provisions. This was, of course, the opposite strategy from that employed in August, and it was obviously, a substantial risk. But Pym was, after all, not looking for, or expecting, the unanimous endorsement of the House. He was looking for a mere majority, as a vote of confidence to take to the public. Besides, the impact of a religious and secular Remonstrance, supported by a majority of the House, however small, would have been substantially greater than any one part by itself. The conditions which prevailed justified, and in fact required, that the opposition issue a cumulative and definitive statement of its position.

The form of the Remonstrance was extremely disjointed, but was roughly organized in three parts. The first 133 clauses generally offered a litany of past ills and grievances. Paragraphs 114-180 represented the actions already taken by the House to remedy those ills. The remaining 26 clauses presented the Commons' plan to prevent future discord. 136 Within that very general framework, the Remonstrance exhibits little continuity or consistency in either subject matter or style.

The first section begins with a general accusation: the laws and liberties of the Kingdom had been subverted by a faction composed of Papists, Bishops and corrupt clergy, and evil ministers. The activities of this faction are then enumerated in a long list of grievances. Here the style suddenly changes. There' is no order to the.list and no organization, but for the most part it reflects grievances which were either religious, political, or economic. 
The religious grievances included the abuses of the Court of High Commission, (a "Romish Inquisition"), the attacks on Puritanism through the imposition of oppressive Canon Law, and the increase of popish innovations in Church ceremonies. The economic grievances offered a wide range of complaints including Monopolies, Ship Money, Tonnage and Poundage, Knighthood service, and Forced Loans. The political abuses dealt generally with the dissolution of the three previous Parliaments, with the imprisonment of the House membership, and with the activities of the Court of Star Chamber.

Midway through this section the style changes once again, (Clause 60) and the Remonstrance offers another description of the faction and an outline of their three part plan to undermine ecclesiastical and civil government:

62. I The government must be set free from all restraints of laws concerning our persons and estates.

63. II There must be a conjunction between Papists and Protestants in Doctrine, Discipline, and ceremonies....

64. III The Puritans, under which name they include al1 those that desire to preserve the Laws and Liberties of the Kingdom, and to maintain religion in the power of it, must be either rooted out of the Kingdom with force, or driven out with fear.

There then follows a long historical narrative, describing in rough chronological fashion, the path taken by the "faction" to achieve its ends. The narrative focuses, of course, on Strafford and Laud, portraying them as the principle architects of the design.

The middle section begins abruptly, (clause 113) with a. similar list of remedies enacted by Parliament. The remedies include the ${ }^{137}$ Gardiner, Documents, op. cit., p. 217. 
the abolition of Ship Money, The Courts of High Commission and Star Chamber, and Tonnage and Poundage, the suppression of Monopolies, the impeachments of Strafford, Laud, Windebank, and Finch, and the passage of the Triennial Act and the Act of Dissolution. Parliament's accomplishments in the area of religion are less clear. The "Canons and the power of Canon making" are said to have been "Blasted" by both Houses. Other "exellent laws and propositions...for removing the inordinate power, vexation, and usurpation of the Bishops" are said to be "in preparation", (Clause 137).

The section then dissolves into a singularly interesting narrative in which the authors defend the Parliamentary program of reform in the face of imaginary accusations, supposedly directed at the House by the "Faction". Throughout this section the King and the Faction are referred to in the third person. The whole middle section in fact, adopts an "us against them" narrative format:

They have endeavored to work in His Majesty ill impressions and opinions of our proceedings, as if we had altogether done our own work, and none of his.... (Clause 145)

The authors had obviously abandoned any pretense that this was meant to be a petition to the King.

The final clauses of the Remonstrance (180 ff) outline the opposition's final measures for reform. The program essentially contains proposals relating to the two major areas of concern; the need for religious reform, and the issue of the King's councillors. The religious clauses simply reiterate the intention to remove the Bishops from temporal offices, "so the better they might with meekness ${ }^{138}$ Gardiner, Documents, 오. cit. p. 224 . 
apply themselves to the discharge of their functions," (clause 183). They also assert that any new ecclesiastical doctrine would be subject to Parliamentary approval.

The political clauses dealing with the King's ministers propose not only that the King's councillors be subjected to similar Parliamentary confirmation, but that confirmation be guided by a strict set of limitations imposed by the House.

For the most part, the first two sections of the Remonstrance are considerably less important than the final set of clauses. In the first place, the Remonstrance as a whole is compromised by the fact that it reduces the complex political and religious struggle of the period to a political absurdity. The political allegiances which the Remonstrance"describes, the "faction" of Papists, Protestants, and royal ministers, simply did not exist in any real sense. Secondly, the grievances outlined in the first section had generally been remedied by November 1641 , as the second and middle section makes clear. The important clauses of the Remonstrance are those contained in the final section, specifically those which deal with fundamental concerns about religious doctrine, ecclesiastical government and the appointment of the King's ministers. It is these clauses which generated the decisive debates.

The debate began on 9 November, having been delayed one day from the first reading on the 8 th. Clarendon described the initial reaction to the bill. "The House seemed generally to dislike it; many saying that it was unnecessary and unseasonable."139 It was ${ }^{139} \mathrm{Clarendon}$, 오. cit., p. 417. 
of course unnecessary because it cited grievances that had already been redressed, and it was unseasonable because it was brought in while Charles was still fulfilling his responsibilities in scotland. Clarendon was obviously still laboring under the assumption that the Remonstrance was meant for Charles. The debate continued on the 10th, the $15 \mathrm{th}$, the $16 \mathrm{th}$, the $19 \mathrm{th}$, the $20 \mathrm{th}$, and concluded on the $22 \mathrm{nd}$. In the initial debates, the House concentrated on those clauses which recited the past conditions of the Kingdom, and which assigned responsibility for them. There were a number of ammendments made in the language to soften accusations and to clarify given positions on past issues. The only major concession won by the Royalists seems to have been the expulsion of a clause, critical of the Book of Common Prayer. By the 22nd, the bulk of ammendments had been made and the Remonstrance remained very much the same.

The essence of the debate on the $22 \mathrm{nd}$, was centered on four major aspects of the Remonstrance. The first, was that mentioned by Clarendon, and reiterated by Falkland, "this casts a concealing of delinquents upon the King," and again by Edmund Waller, "This is rather a pre-monstrance, than a re-monstrance."140 The rehearsal of so many past grievances, in so voluminous a manner, was generally felt to be unjust, and severely injurious to Parliament's future relationship with the Crown. The religious debate, interestingly, focused more on the aspersions which the Remonstrance cast on the clergy, than on any major reform which it might have proposed.

${ }^{140}$ Sir Ralph Verney, Notes on the Proceedings of the Long Parliament, Camden Society Publications, $\frac{1844, \text { p. } 121-124}{1}$ 
In fact, the religious reformations were relatively insignificant, at least compared to those Parliament had already considered during the year. The Remonstrance ignored any attempt to revive the provisions of the Root and Branch Bill, and merely reiterated the principle of the Bishops Exclusion Bill by removing the Bishops from any temporal employments. 141

If there was anything which represented a major challenge it was the statement that religious uniformity would be imposed "by such Rules and Orders of Dicipline as are established by Parliament..."142 This provision asserted a power for Parliament which had by tradition, custom, and Law, rested with the Church itself, under the direct control of the King. It was, in this sense, revolutionary.

Obviously, the other major contentious provision was that dealing with the powers of appointment to the offices of State, and in this the Grand Remonstrance parted company with even a pretense of legal justification.

That His Majesty be humbly petitioned by both Houses to employ such Counsellors, Ambassadors, and other Ministers, in managing his business at Home and Abroad, as Parliament may have cause to confide in, and without which we cannot give his Majessty such supplies for the support of his own estate.

There was, in short, simply no legal grounds on which to support this proposal, which amounted, in the last analysis, to legal and constitutional extortion.

${ }^{141}$ Rushworth, op. cit., p. 450. (Clause 184.)

${ }^{142}$ Rushworth, op. cit., p. 450 . This statement is reiterated in Clause 183, in somewhat different wording. 
Implicit in the legal, constitutional, and religious questions involved in this event, was an over-riding concern which emanated from the Remonstrance, and which was, ultimately of a more fundamental importance. The provisions of the Grand Remonstrance contained a major, and for some, catastrophic, breach with the hereditary order which had supported the House, its members, and the entire constitutional balance for centuries. It was quite obvious by the 22nd, that the Remonstrance was intended for universal publication and distribution, and that, in itself, was not only a violation of Parliamentary custom, but was an appeal to revolutionary tactics. Over and over during the debate, the members objected to the fact that the Remonstrance was no longer an address to the king for redress of grievance, but a Remonstrance to the public at large. Sir Edward Dering, in a later reflection on the whole controversy, summarized his feelings, and those of a major portion of the House, "When I first heard of a Remonstrance...I did not dream that we should Remonstrate downwards, tell stories to the people, and talk of the King as of a third person."144 In addition, it was equally obvious that the Remonstrance would never enjoy the support, much less the ratification of the House of Lords. That the Remonstrance would be released for public consumption without that endorsement constituted, like the Order on Innovations in September, an unacceptable violation of Parliamentary law. In the words of Sir John Culpepper, "The declaration going but from this House, goes but on one leg. "145

${ }^{144}$ Zagorin, op. cit., p. 269 , note 1 .

${ }^{145}$ Verney, op. cit., p.122. 
Any bil1, Remonstrance, or petition which embodied in its provisions such a fundamental assault on the constitutional order of the Kingdom, could not possibly have enlisted unanimous support. For al1 of the importance of its individual clauses, the whole of the Grand Remonstrance was greater than the sum of its parts. It represented a cumulative challenge to the hereditary framework of English government.

The division which the Remonstrance provoked afforded the Opposition a slim victory of 11 votes, with 159 supporting the measure, and 148 rejecting it. Immediately the opposition moved to have the House's action recorded with an accompanying order indicating its intention to publish the bill. That motion was met with an equally violent debate, but with essentially the same result for the majority. Finally, an attempt to record an official minority report of protest to the Remonstrance, initiated by Geoffery Palmer, was vigorously challenged, and ultimately rejected, but not before Palmer was ejected from the House, and a wild demonstration had erupted, in which śwords were drawn and sides taken. "'I thought, wrote an eyewitness, we all sat in the valley of the shadow of death; for we...had catched at each others locks, and sheathed our swords in each others bowels." 146 Once reason had been restored, the House adjourned at an unprecedented hour of two A.M.

"It the Remonstrance had been rejected, I would have sold all I had the next morning, and never seen England anymore."147 Cromwell's ${ }^{146}$ Gardiner, op. cit., p. 77, (Sir Philip Warwick). 147 clarendon, op. cit., p. 432. 
famous remark on the Remonstrance is a reflection of the political extremeties which the critical events of the last twelve months had produced. The House was indeed, irreconcilably, and equally divided, with both sides committed to the defense of altogether different political principles. The King's response to the Remonstrance essentially guaranteed that that division could never, and would never, be repaired. Had Charles been.willing or able to accept any of the proposals in the Remonstrance, or even derivations of them, he might have been able to create a political middle ground toward which both sides might have been able to gravitate. As it was, Charles rejected the Remonstrance out of hand, and specifically condemned its two pivital provisions dealing with the Bishops exclusion from Parliament, and the choice of Royal ministers. His irrevocable and uncompromising position, and in fact, his subsequent attack on the leaders of the opposition, ultimately forced the members of the House to commit themselves to a position, either in support or opposition to Charles' final defense of his constitutional rights. The opposing parties in the vote on the Grand Remonstrance very soon became the opposing parties in the Civil War.

The Grand Remonstrance reflects, both in the finished document, and in the history of its development, the issues which ultimately led the House of Commons to divide and move toward Civil War. Beyond that, the Remonstrance reflects the fact that those issues developed during the limited tenure of the Long Parliament, not as a result of a long terin revolutionary movement. They developed in the context of a fundamental disagreement, first between Charles 
and the House of Commons, and then between parties within the Long Parliament itself, over the essential principles of government in a constitutional monarchy. 
A. Primary Sources:

1) Coates, Wilson H., ed. The Journal of Sir Simonds D'Ewes, Archon Books, 1970 .

2) Diurnal Occurrances in Parliament, 23 July-16 November, Microfilm Yale Center for Parliamentary History.

3) Hyde, Edward, Earl of Clarendon, The History of the Rebellion and the Civil Wars in England, W.D. Macray, ed. Clarendon Press, $18 \overline{88}$.

4) Journals of the House of Commons, Volume 11, 1640-1641, University of Washington Library. 5) Journals $\frac{\text { of }}{\text { Har }} \frac{\text { the }}{1 i a n \text { Mss, } \frac{\text { House }}{6444} \text { of }}$ Commons, Extracts, British Library,

6) Notestein, Wallace, ed. The Journal of Sir Simonds D'Ewes, Yale University Press, 1923.

7) Rushworth, Historical Collections, Volme IV, 1640-1641.

8) Verney, Ralph, Notes on the Proceedings of the Long Parliament, Camden Society Publications, $18 \overline{84 .}$

B. Secondary Sources:

1) Admanson, J.H. and Folland, H.F., Sir Harry Vane, Gambit, Boston, 1972.

2) Aiken, W.A. and Henning, B.D. Conflict in Stuart England, Archon Books, 1970.

3) Aylmer, G.E. The Struggle for the Constitution, 1603-1689, Blandford Press, London, $196 \overline{3}$.

4) Brett, S. Reed, John Pym, John Murray, London, 1940.

5) Brunton, D. and Pennington, D.H., The Members of the Long Parliament, Archon Books, $19 \overline{68 .}$ 
6) Butterfield, H. The Whig Interpretation of History, Scribner's, New York, 1951.

7) Cobbett, Parliamentary History of England, Bagshaw, 1807.

8) Davies, Godfrey, The Early Stuarts, Oxford, Clarendon Press, 1959.

9) Elton, G.R., Studies in Tudor and Stuart Politics and Government, Vol. 2, Cambridge University Press, 1974.

10) Forster, John, The Debates on the Grand Remonstrance, John Murray, $1 \overline{860}$.

11) Gardiner, Samuel R., History of England, Volumes, IX \& X, AMS Press, 1965.

12) Gardiner, Samuel R., The Constitutional Documents of the Puritan Revolution, Oxford, Clarendon Press, 1889 .

13) Gooch, G.P., English Democratic Ideas in the 17th Century, Harper and Row, 1959.

14) Hexter, J.H. The Reign of King Pym, Harvard University Press, Cambridge, 1959 .

15) Hill, Christopher, The Intellectual Origins of the English Revolution, Oxford University Press, 1949 .

16) Judson, Margaret, The Crisis of the Constitution, Rutgers Press, 1949.

17) Kearney, H.F., Strafford in Ireland, Manchester University Press, 1959.

18) Keeler, Mary, The Long Parliament, American Philosophical Society, Philadelphia, 1954.

19) McIllwain, C.H., The High Court of Parliament, Archon Books, 1962.

20) Petrie, Sir Charles, The Letters of Charles I, Casse1 \& Co., 1935.

21) Richardson, R.C., The Debate on the English Revolution, St. Martins, New York, 1977 .

22) Roberts, Clayton, The Growth of Responsible Govènment, Cambridge University Press, 1966.

23) Russe1l, Conrad; The Crisis of Parliaments, Oxford University Press, 1971 . 
24) Russe11, Conrad, ed., The Origins of the English Civil War, London, Macmillan, 1973.

25) Stone, Lawrence, The Causes of the English Revolution, 1529-1642, London, Rut Tedge, 1972.

26) Tanner, J.R., English Constitutional Conflicts of the Seventeenth Century, Cambridge University Press, 1928.

27) Trevelyan, G.M., England Under the Stuarts, G.P. Putnam's, New York, 1910 .

28) Wedgewood, C.V., Strafford, Jonathon Cape, 1938.

29) Zagorin, Perez, The Court and the Country, Atheneum, New York, 1971 .

C. Articles:

1) Christianson, Paul, "The Causes of the English Revolution:

A Reappraisal," Journal of British Studies,

$15,1976$.

2) Christianson, Paul, "The Peers, the People, and Parliamentary Management in the first Six Months of the Long Pariament", Journal of Modern History, 非49, 1977.

3) Coates, W.H. "Some Observations on the Grand Remonstrance", Journal of Modern History, 非1, 1932.

4) Hexter, J.H. "Power Struggle, Parliament, and Liberty in Early Stuart England," Journal of Modern History, 非50, March 1978 .

5) Kershaw, R.N. "The Elections to the Long Parliament," English Historical Review, Vol. 38, 1923.

6) Kishlansky, Mark, "The Emergence of Adversary Politics in the Long Parliament;" Journal of Modern History, 非49, December 1977.

7) Russe11, Conrad, "Parliamentary History in Perspective, 1604-1629," History, 61, 非201, 1976.

8) Russe11, Conrad, "The Theory of Treason in the Trial of Strafford," English Historical Review, 非8, 1965.

9) Schoolcraft, H.I. "The Genesis of the Grand Remonstrance", University of Illinois Studies, Volume 1, 1902. 


\section{THE SOURCES}

It has been my intention to support this thesis on the Grand Remonstrance through the direct, first-hand evidence available in the primary sources. To the extent that that has been possible, I feel that my conclusions have been well documented. It would be naive, and, in fact, inaccurate, to assume that a11 of the evidence has been explored. The problem has been one of availability. I have been able, through the generosity of the Yale Center for Parliamentary History and the British Museum, to obtain microfilm of both the Commons Journal and the Diurnal Occurrances. The other primary sources have been made available from local and regional libraries. However, there are other important sources that remain unexplored, either because they have not yet been edited or published, or because they were simply not available to me. I would include the diaries of Sir Thomas Peyton, John Moore, John Holland, and the memoirs of the Earl of Manchester in this list. One would also have to include the section of the D'Ewes Journal which covers the period from the death of Strafford to the Parliamentary recesses in September 1641. There are, in addition, Committee Books and individual notebooks of the daily proceeding in the House, such as Geoffery Palmer's that might provide vital information.

The principal sources that were used, Rushworth, The Commons Journals, D'Ewes Journa1, Verney's Notes on the Proceedings in the Long Parliament, and Clarendon's History, represent the standard 
primary sources for the period. The Commons Journals are the most valuable and important. They provide an official record of the daily events in the House of Commons, including original motions, divisions, cormittee assignments, and appointments. They are, in one sense, limited because they contain only those entries allowed with the common consent of the members. Nonetheless, the wealth of information they contain makes them essential for any study of the period. D'Ewes Journal provides a more intimate view of events. His journal contains, in addition to a record of his own participation, an account of the personal reactions and motivations of the other members to all of the major issues of the Long Parliament. It is a daily record, scrupulously kept, of the business before the House, and it provides a perfect complement to the official version offered in the Commons Journals. Unfortunately, it is, at present, available only for the first five and last three months of the period under study. The remainder of the Journal is currently being edited. Rushworth provides a combination of both $D^{\prime}$ Ewes and the Journals. It is an enormous collection of both relevant documents and complete speeches. It was originally meant to be an official record of House proceedings and it reflects that intention throughout. It is not as complete as the Commons Journals in this respect, but it provides a record of speeches which are not always available in D'Ewes. It is therefore extremely useful. Verney's Notes are limited to the last month of the period under study, but they contain a number of interesting excerpts from speeches, particularly during the debate on the Grand Remonstrance, as well as corroborating references to 
important motions in the House. Clarendon's History is, at least in part compromised by intrusive political prejudice in favor of the Royalist cause, but his account is fullsome and extraordinarily interesting as a retrospective history of the events. Clarendon's account, is, like D'Ewes', a highly personal narrative. The Diurnal Occurrances represent fragments of the Commons Journals, or, in some cases the result of incomplete notes on the proceedings acquired from willing members of the House. They were meant to be Parliamentary newsletters and were composed of whatever daily information might be available. They are inaccurate and disorganized, and, for the most part, unreliable as far as dates are concerned. They are not therefore useful as direct, verifying evidence. However, in those cases where they can be corroborated by entries in the Commons Journals, they provide an interesting insight into the description of Parliamentary activities offered the public.

Despite any individual limitations they might contain, all of the sources, in combination, offered a wealth of first-hand evidence from which I could draw needed information. I was able, in a sense, to compensate for the weakness of one source with the strengths of the others. I feel confident that the evidence supplied by these sources lays a solid foundation for the conclusions which $I$ have reached in this thesis.

The secondary sources provided the framework of historiographical argument which prompted the thesis in the first place. For the immediate purposes of this thesis I would mention three principle works. I am indebted to Henry Lawrence Schoolcraft's article, 
"The Genesis of the Grand Remonstrance", which, though somewhat outdated (1902), nonetheless provided a very useful chronological outline of the Remonstrance. Schoolcraft's purpose was somewhat shortsighted. He did not attempt to establish a direct relationship between the Grand Remonstrance and the general history of the Long Parliament, nor did he consider the wider problem of causation. His purpose was to prove that John Pym was not the sole author of the Remonstrance. His scope was therefore limited. Nonetheless his article provided a number of useful and important insights into the daily activities of the House, and not a few clues to the motivations of the principle actors in the drama. I would also mention Gardiner's History as a prerequisite to any study of the Long Parliament, and the period as a whole, simply because it offers a consistent and lucid narrative survey of the events. Finally I must cite Perez Zagorin's The Court and the Country as perhaps the most helpful source of information. One can disagree with the general political paradigm used by Zagorin, with his division of the Stuart political nation into court and country parties, but the general focus of the work, and the perceptive analysis of the central political issues is accurate and extremely useful.

of the works devoted to specific studies, both Keeler's Long Parliament and Brunton and Pennington's The Members of the Long Parliament were essential. Roberts' The Growth of Responsible Government was particularly useful for its general introduction to the principles of 17 th century inter-governmental relationships, as was Brett's John Pym for its careful and judicious evaluation of one of the major figures of Parliamentary history. 
The general surveys of Stuart England have been either supported or rejected on the basis of the particular approach they took to the general question of causation. This thesis has questioned the whole premise of a revolution preceeding the English Civil War. I have therefore rejected the basic historical arguments contained in the works of Tawney, Stone, and Hill. I have done so, however, with the understanding that their research has greatly enlarged the general knowledge of 17 th century socio-economic conditions. My support of Elton, Hexter, Christianson, and Russe11, and their collective assumptions about the causes of the Civil War, derives from my sincere belief in the fundamental importance of the prevailing political relationships in early Stuart England. 